Claremont Colleges

Scholarship@ Claremont

Pomona Faculty Publications and Research

Pomona Faculty Scholarship

1-1-1997

\title{
A Classical Stage for the Old Nobility: The Strada Nuova and Sixteenth-Century Genoa
}

George Gorse

Pomona College

\section{Recommended Citation}

Gorse, George, "A Classical Stage for the Old Nobility: The Strada Nuova and Sixteenth-Century Genoa," The Art Bulletin 79 (1997), pp. 301-327

This Article is brought to you for free and open access by the Pomona Faculty Scholarship at Scholarship @ Claremont. It has been accepted for inclusion in Pomona Faculty Publications and Research by an authorized administrator of Scholarship @ Claremont. For more information, please contact scholarship@cuc.claremont.edu. 


\title{
A Classical Stage for the Old Nobility: The Strada Nuova and Sixteenth-Century Genoa
}

\author{
George L. Gorse
}

Sixteenth-century Genoa produced a distinctively new type of urban space in the Strada Nuova (or, since 1882, the Via Garibaldi) - the residential palace street or linear piazzadesigned to legitimize and enhance the authority of a ruling elite. ${ }^{-}$Laid out in 1550-51 and built between 1558 and 1591, the Strada Nuova (Fig. 1), when taken as a whole, represents two significant themes for the history of Genoa and the interpretation of Renaissance cities. First, this major example of Italian Renaissance architecture and urban planning was conceived and, indeed, functioned as a classical stagelike space for the old nobility, who governed and controlled the tightly restrictive Genoese aristocratic republic of $1528 .^{2}$ This scenographic urban enclave proclaimed the exclusive social, economic, political, and ceremonial position of the old noble families who commissioned ostentatiously rich, decorated palaces along the Strada Nuova's central, monumental perspective axis (Figs. 1, 19, 23). As such, the Strada Nuova became the major public presentation space for the regime these families led.

Second, as an urban environment, the Strada Nuova highlighted the newly regained international status of Genoa, which surpassed that of even the medieval Genoese maritime

The first version of this paper was read at the Renaissance Society of America conference on "The City in the Renaissance" at Columbia University, New York, in 1988. I thank members of the RSA, in particular Charles Mack, Charles Burroughs, Kathleen Weil-Garris Brandt, Janet Cox-Rearick, Howard Saalman, and Charles Stinger, for their early suggestions and encouragement. Professor Irving Lavin at the Institute for Advanced Study in Princeton, N.J. sharpened my analysis during a fellowship vear in 1989-90. A second draft was read at the Bronowski Symposium at the University of California, San Diego, in 1991; and I am very grateful to R. Burr Litchfield, Geoffrey Symcox, John Marino, Judith Brown, and Jack Greenstein for their careful reading, criticism, and editing of this study. Further refinements came from Claire Farago and Steven Epstein at the University of Colorado, Boulder. Editor Nancy Troy and an anonymous reader improved the final text; and I thank Lory Frankel for careful editorial work. Throughout, I received generous support from the Pomona College Research Committee. Finally, I dedicate this article to my Genoese friends Ennio Poleggi and Giorgio Doria, for their inspiring scholarship on la storia urbanistica genotese.

1. This study attempts a unified and integrated interpretation of the Strada Nuova, based on the earlier work of two major scholars: Mario Labò, "Strada Nuova (più che una strada, un quartiere)," in Srritti di storia dell'arte in onore di Lionello Venturi, I. Rome, 1956, 403-10; and Ennio Poleggi, Strada Nuova, una Lottizarione del Cinquecento a Genova (1968), 2d ed., Genoa, 1972. Important recent additions are: on palace investment, Giorgio Doria, "Investimenti della nobiltă genovese nell edilizia di prestigio (1530-1630)." Studi storici, XXVII, 1986, 5-55: and on the Strada Nuova in historical context, Bettina-Martine Wolter, "Genueser Palastarchitektur zwischen Staatsreform und Machtstreben," in Kunst in der Republik Genoa 1528-1815, ed. Mary Newcome Schleier, Fraukfurt, 1992, 32-42. General guides include Fiorella Caraceni, A Renaissance Street: Via Garibaldi in Genoa, Genoa, 1993; Le Strade Nuove, Guide di Gemova, n.s., no. 9, Genoa, 1986: I Palazsi delle Strade Nuoze, Guide di Gemova. n.s., no. 10, Genoa, 1986; Piero Torriti, Tesmi di Strata Nuova, la Via Aurea de genovesi, Genoa, 1982.

2. For general historical studies of the Genoese republic of 1528, set Claudio Costantini, La repubblica di Genova, Turin, 1986; Rodolfo Savelli, La repubblica oligarchica: Legislazione, istiluzionie ceti a Genova nel Cinquecento, Milan, 1981: Edoardo Grendi, La reputblica aristocratica der Genonesi, Bologna, 1987.

3. The usefulness and indeed instrumentality of artistic patronage and representation in shaping, rather than simply reflecting, sociocultural pro- republic, as the leading banking and commercial center of the Spanish Hapsburg Empire in northern and central Europe, the Mediterranean, and the New World. As the bankers of the Hapsburg monarchy, the inhabitants of the Strada Nuova put their abundant economic resources and humanistic culture to good use to shape a "modern" image of their cosmopolitan port city. ${ }^{3}$ This was assuredly a major achievement of private-to-public patronage as well as selfconscious display-pubblica magnificenzia (public magnificence)-by a rich, ruling elite. ${ }^{4}$

In the early seventeenth century, Peter Paul Rubens publicized the Strada Nuova with its magnificent palaces (Figs. 26 , 29, 31, 32), along with other major palaces, churches, and villas, in a deluxe folio volume, divided into two parts, featuring full-page engraved illustrations (including measured ground plans, sections, and full facade views). A classical image of the Genoese nobility, the Strada Nuova became the centerpiece of Rubens's Palazzi di Genova, which constituted the first monographic architectural study of a patrician ensemble, an influential model for northern European noble patrons. ${ }^{5}$ The Strada Nuova represented a classical scaena frons (scenic front) for the old Genoese nobility,

grams, argued in this paper, critiques Robert Loper's "hard times" theory of artistic patronage, a result (Lopez contends) of a lack of more "productive" forms of investment (such as commerce, banking, and so on). See Robert 1.opez. The Three Ages of the Renaissance. Boston, 1970, 15, 50-51 and passim. For a discussion of this patronage-audience problem, which cites an earlier. unpublished version of my essay, see Richard Goldthwaite, Wealth and the Demand for Art in Italy 1300-1600, Baltimore, 1993, 14, 188.

4. On magnificenzia as a key motive for Renaissance artistic patronage, see A. Fraser Jenkins, "Cosimo de' Medici's Patronage of Architecture and the Theory of Magnificence," Joumal of the Warburg and Corurtauld Institutes, XxxII, 1970, 162-70; Richard Goldthwaite, The Building of Renaissance Florence: An Economic and Social History, Baltimore, 1980, 83-84 and passim.

5 . This normative purpose, addressed to northern patrons, is announced at the outset of Rubens's preface to his Palazzi di Gmozia: "Al benigno lettore Vediamo che in queste parti, si va poco a poco invecchiando \& abolendo la maniera d'Architettura, che si chiama Barbara, o Gothica; \& che alcun bellissimi ingegni introducono la vera simmetria di quella, conforme le regole de gli antichi, Graeci e Romani, con grandissimo splendore \& ornamento della Patria" (To the kind reader. We see that in these parts, little by little the manner of Architecture, that which we call the Barbaric or Gothic, is becoming old and extinct; and that a few very beautiful talents are introducing the true symmetry of that which conforms to the rules of the ancient Greeks and Romans, with very great splendor and ornament to the Country). Rubens published his book in two parts in Antwerp on May 4, 1622, perhaps in collaboration with Balthasar Moretus and the famous humanist Plantin Press (see Max Rooses, Petrus-Paulus Rubens en Balthasar Moretus, Antwerp, 1884, 118 for Rubens's payment documents to the Plantin Press on May 4 and June 28, 1622, for binding the Palazzi di Genova). Part 1 contained 72 plates (including five Strada Nuova palaces in 23 plates of fifteen palaces and villas altogether), while part 2 had 67 plates (with six Strada Nuova palaces in 18 plates of nineteen palaces and villas with four churches added at the end), all engraved by Nicholas Ryckemans, an Antwerp collaborator and follower of Rubens: "Cum privilegijs, Regis Christianissimi Principum Belgarum, et Ordinum Bataviae. Nicolaes Ryckemans sculp." (With the privileges of the very Christian King, of the Rulers of the Belgians, and of the States General of the United Provinces. Nicholas Ryckemans, sculptor), which appears at the bottom of p. 1. Because of its popularity, there were many subsequent editions of Rubens's Palazzidi Genoua (in 1652, 1663, 1708, and 1775), printed from the 
which greatly impressed visiting European monarchs, dignitaries, and travelers as a sumptuous "royal court center" within the city. ${ }^{6}$ This luxurious presentation street was thus a major example of architecture as metaphor or stage set for social aggrandizement-coherent in form, dramatic in content, hierarchical in meaning, serving an elite-which appears frequently in the history of cities. Such an urban theater concept was theorized in antiquity and the Renaissance in the writings of Leon Battista Alberti, Filarete, Andrea Palladio, and others, and contributed to the definition of the urban type of theatrical stage-set presentation for early modern absolutist regimes that was common in Europe during the Baroque era. $^{7}$

Sebastiano Serlio's famous chapter 3, for instance, of his Second Book on Architecture, first published in 1545, articulates not only an image of the city based on Vitruvius's description of a classical tragic stage represented in one-point perspective but also an appropriate setting for superior (that is, larger-thanlife) social and moral action (Fig. 2):

Houses for Tragedies must be made for great personages, for actions of love, strange adventures, and cruel murders (as you read in ancient and modern Tragedies), happen always in the houses of great Lords, Dukes, Princes, and Kings. Therefore in such cases you must make none but stately houses, as you see here in this figure [of the tragic stage set]. ${ }^{8}$

To Serlio and other Renaissance theorists, the city was a stage where the articulation of Aristotle's dramatic unities of place, time, and action were symbolically and physically heightened by architecture, which created a psychologically charged frame and indeed took part in the play of serious (that is, tragic) social and ethical actions. ${ }^{9}$ What was left unsaid here, but requires expression with regard to the Strada Nuova, is that the concept of a coherent and imposing stage set in urban planning carried with it the specific message of

same copperplates, after the artist's death in 1640, when the two parts were separated into two volumes and retitled Patazsi Antichi di Genova (part 1) and Patazzi Moderni di Genova (part 2), including major examples of Genoese architecture in the Alessian classical style from the second half of the 16 th and early 17 th centuries. These exempla were selected by Rubens, who was artistic director and entrepreneur of the project. probably beginning as early as his visit to Genoa in Juh-Angust 1607 as part of the court entourage of Duke Vincenzo I Gonzaga. The Strada Nuova palaces were clearly central to Rubens's interests, although they account for less than a third of the palaces, villas, and churches he illustrates. Among the important sources for Rubens's Palazzi di Genowe is a precious volume of drawings, collected and commissioned by Rubens from anonymous Genoese architects and designers, now preserved in the Royal Institute of British Architects in London. Two of these drawings are discussed below (Figs, 29,32), being the designs from which the engravings were executed (in exact order and size with figure numbers, notations, and traced lines for transfer). Previously, the Royal Institute volume was discussed and illustrated selectively by Mario Labò, I Palazzi di Genota di Pietro Paolo Rubens e allri sorilti d'architetiura, Genoa, 1970, 12-21 and passim; and catalogued by Jill Lever et al., Catalogue of the Dravings Collection of the Royed Institute of British Architects, Vol. O-R, Loudon, 1976, 158-73. Di. Herbert Rott of the University of Augsburg is presently preparing a comprehensive study of the institute's album as part of a Compus Rubeninnum volume on Rubens's Palazti di Genown, which will cast further light on Rubens's publication and Genoese architectural practice. Recently, Donna Maria Salzer, in an unpublished dissertation, "Galeazzo Alessi and the Villa in Renaissance Genoa" (Ph.D. diss., Harvard University, 1992), discussed the volume in most illuminating wavs, pertaming to Galeazzo Alessi's Genoese villas. For further discussion of Rubens's Palazzi di Gemova, see the facsimile edition of Peter Paul Rubens, New York, 1968; Ida Maria Botta, "P.P. Rubens e il volume i 'Palazí di Genova," " in Rubens e Genove, ed. Giuliana Biavati et al., exh. cat.. Palazoo
2 Sebastiano Serlio, The Tragic Theatre Set, from The Book of Architecture, London, 1611 (New York, 1980), bk. 2, chap. 3, fol. $25 \mathrm{v}$

the patrons' claims to power and privilege, aimed at local citizens and the foreign audiences who viewed it. Ancient and Renaissance theorists associated this type of urban planning with "good government," that which justified, rationalized, preserved, and acted out the predominant social order and institutional framework through an architectural-decorativespatial construct, an imposed visual language or physical rhetoric.

All other architectural styles, including the Gothic, in combination with "indecorous" classical elements-that is, fractured combinations of "noncanonical" styles-were for Serlio and other Renaissance theorists inappropriate for the "tragic" stage, and thus detrimental to established power

Ducale, Genoa, 1978, 59-84; Wolfgang Lot et al., Giateazo Alessi c laxchiteltury del Cinquecento, Genoa, 1975, passim.

6. For travel descriptions of Genoa and the Surada Nuova, emphasizing its royal character during the late 16 th through the early 20 th centuries, see Poleggi, 425-35.

7. The classical statement of this stage-city simile is by Vitrusvius, The Tin Books on Architecture, trans. Morris Morgan, New York. 1960. bk. 5, chaps. 3-9; Leon Battista Alberti, On the Art of Building in Ton Books, trans. Joseph Rykwert et al., Cambridge, Mass., 1988, bk. 8, chap. 7; Wolfgang Lotz. "SixteenthCentury Itatian Squares," in Studies in Valion Renaissonte Anhitecture. Cambridge, Mass., 1977, 74-139. The best pictorial examples of this analogy would be the so-called Urbino Panels that show Renaissance ideal city views (ca. 1490) as largely uninhabited, classical stage sets in one-point perspective; see Richard Krautheimer, "The Tragic and Comic Scene of the Renaissance: The Baltimore and Urbino Pancls," in Studies in Early Christion, Mediezal, and Remaissatuce Art, New York, 1969, 345-60); Leonardo Benevolo, Storia della ritti, Rome, 1978, 535-604: Spiro Kostof, A History of Arthiterture: Settings and Rituals, Oxford, 1985, 402-31.

8. Sebastiano Serlio. The Book of Architeture (London, 1611), New York. 1980, bk. 2, chap. 3, fol. $25 \mathrm{v}$.

9. Aristotle, On Poetics, trans. Ingram Bywater, Chicago, 1952, chaps. 8, 23 Particularly significant is this discussion of Aristotelian poetic-dramatic theory (modes), which appears precisely in the treatise section on Renaissance "perspective" (Figs. 2-4), a reformulation of classical concepts of literature and thetoric (mimesis, istorin, and ut picturn presis). theater, and city and country life in terms of 15 th- and 16 th-century visual conventions of representation. Cf. Serlio, The Book of Architecture, bk. 2; Erich Auerbach. Mimesis: The Representation of Reality in Western Literature, trans. Willatd Trask, Princeton, N.J., 1953; and Rensselaer W. Lee, Ut Pintura Poesis: The Humrnist Theory of Painting. New York, 1967. 
3 Serlio, The Comic Theatre Set, from The Book of Architecture, bk. 2 , chap. 3 , fol. $25 \mathrm{r}$

relationships. ${ }^{10}$ Such elements devalued the patrons' (that is, the main actors') status by breaking down the unities of place, time, and action in favor of the lesser dramatic modes of "the Comical, to play Comedies in," or the rustic, untamed, pastoral, countryside settings of the "Satirical for Satyrs" (Figs, 3, 4)."

Perhaps more than any other Italian or European sixteenthcentury example, the Strada Nuova represents the interaction of stage design and urban planning to create an aristocratic neighborhood intended to separate out, highlight, and dramatically solemnize the lives of an elite group of family patrons within a city. A significant point is that this project resulted from private family patronage, supported and facilitated by the communal government. ${ }^{12}$ This private-to-public governmental process in Genoa contrasted with other Italian city-states where the public authority of communal governments or princely courts triumphed over the rights and privileges of private family groups. Traditionally, in Genoa, private noble families propelled public communal policy. For the first Genoese commune, formed in 1099, the elite instituted a temporary private, contractual agreement-a compagna communis-between the eight major commercial companies (compagnie), each led by a noble family-consorterial group with its own armed ships, wharf, and urban territory extending up from the harbor front to the surround-

10. Cf. Rubens's introduction to his Palazzi di Genowa (see n. 5 above) where he makes the same arbitrary historical-ethical claims for the "Classical" (the Tragic and its patrons) over the "Gothic or Barbaric" (Comic and Pastoral or Rustic), specifically applied to the Strada Nuova as an urban exemplum.

11. Serlio (as in u. 8), bk. 2, chap. 3, fols. $25-26$

12. The following discussion is based largely on Poleggi, chap. 2, "Il fatto di Strada Nuova ed il suo spazio," 25-43, and documents, 451-86.

13. For this radial, commercial pattern of urban development from the harbor front into the city and the private character of Genoa's early communal power, see Yves Renouard. Le cittì italiane dal X al XIV secolo, 1, trans. Roberto Cippo, Milan. 1975, 264-300; Luciano Grossi Bianchi and Ennio Polegri, Eno cittic portuale del mediores: Genozin nei secoli $X-X V J$, Genoa, 1980, 33-84; Ennio Poleggi and Paolo Cevini, le citta nella storia dllatin-Germona, Rome, 1981.
4 Serlio, The Salyric Theatre Set, from The Book of Architecture, bk. 2 , chap. 3 , fol. $26 \mathrm{r}$

ing mountains and the fortified city gates and walls (Fig. 5).$^{13}$ Not coincidentally, the early commune of 1099 came about during the First Crusade against the Holy Land (1096-1104), emphasizing the close interrelationship among family, church, and commune during military-economic expansion. ${ }^{14}$

From the beginning, Genoa's commune had a private foundation. Politics was based on this infiastructure of private family group power. Old noble families-such as the Embriaco, Salvago, Fieschi, Doria, Spinola, Grimaldi, Pallavicino, Cattaneo, and Lomellini-came from their fortified castles and hereditary lands along the Ligurian coast (Figs. 6, 7) and settled in Genoa during the eleventh and twelfth centuries. ${ }^{15}$ As a result of this demographic change, Liguria became a patchwork quilt of rival small coastal communes (such as Porto Maurizio, Albenga, Noli, Savona, and Lerici), always resisting the centralizing power of Genoa, and these noble family groups with their castles, titles, and landholdings, or feudi (such as the Grimaldi and Doria on the western Riviera and the Spinola, Fieschi, and Fregoso to the north and east), which served as ancestral-agricultural foundations for the military-commercial-church powers of these family groups. While maintaining their titles and feudal lands in the country, the old nobility literally "feudalized" (that is, made feudi of) the city (Fig. 7), securing their urban seats of power in Genoa

23-38. The Genoese chroniclers serve as an important primary source for this early, formative history: Annali genozesi di Caffaro ed dei suoi continuatori, 7 vols. Genoa, 1923-29.

14. On the Genoese and the First Crusade, see the famous first Genoest chronicler, who was himself a member of the expedition, Andrea Caffaro. Amali genovesi, 1, trans. Ceccardo Ceccardi and Giovanni Monleone, Genoa. 1923; and Steven Runciman. A History of the Crusades: 1. The Fïrs/ Crusade and the Foundation of the Kingdom of Jernsalem, Cambridge, 1951.

15. For a discussion of these regional family feudi (fiefs), closely interrelated to their urban strongholds, see Jacques Heers, Genes au XV siéte: Artivite ceconomique et froblemes sociaux. Paris, 1961, 524-43, 644-45; and Steven Epstein. Genoa and the Genoese 958-1528, Cluapel Hill, N.C., 1996, passim. 
5 Plan of Genoa within 12 th-century walls, showing compagnie regions (from Poleggi and Cevini, Le citti nella storia d'Ttalin-Genova, 35, fig. 19)
6 Regional map of Liguria showing communes and family feudi (from Jacques Heers, Genova nel 400: Civiltì mediterranea, grande capitalismo e capitalismo popolare, Milan, 1983, 380, fig. 3)

7 Map of 13th-century Genoa showing late medieval family alberghi territories (no. 24 Piazza S. Matteo) (from Grossi Bianchi and Poleggi, Una città portuale del medioevo: Genova nei secoli X-XVI, 68-69, pl. 3 
8 Cristoforo de Grassi, Bird's-eye view of Genoa, 1597 , showing Genoa in 1481. Genoa-Pegli, Civico Museo Navale (photo: Archivio Fotografico del Comune di Genova)

with tall fortress towers, featured in contemporary views and descriptions of the port (Figs. 8, 11). ${ }^{16}$ These urban towers were surrounded by closely guarded palace clusters within closed, local family neighborhoods (called alherghi) and compagnie associations. ${ }^{17}$ This was a powerful feudal magnate class in charge of a commercial republic.

Opposed to the old nobles were the cives noves-the new nobles and merchant middle class-who came increasingly to the fore as rival groups during the late Middle Ages and early Renaissance. ${ }^{18}$ New noble families-in particular, the Boccanegra and competing Fregoso and Adorno clans-dominated the capitani del popolo and dogiperpetui of the second half of the thirteenth through the early sixteenth centuries. ${ }^{19}$ Elected for life, but frequently remaining for only a brief period owing to
9 Detail of Fig, 8 showing the Castelletto and S.

Francesco with the later Strada Nuova region below and to the right disorder from within and without, the "captains of the people" and "perpetual doges" headed the late medieval and early Renaissance republic. The old nobles were excluded from office because of their factional undermining of the communal government and even the city's sovereignty, which had resulted in foreign occupation and seignorial rule by the more powerful neighboring duchies of Milan, Savoy, and Montferrat and by the kingdom of France. Placed under these restrictions, the Guelph (Fieschi, Grimaldi) and Ghibelline (Doria, Spinola) factions of the old landed nobility continued to have strong links with and exert influence on the Fregoso and Adorno popolare family groups, while the old nobles served in official diplomatic and military capacities, as representatives of Genoa to foreign courts, a class role for which 
they were well suited, or as professional naval and land captains, along with their predominant mercantile enterprises. ${ }^{20}$

Andrea Doria's republic of 1528 returned the old nobility to power through their expulsion of the French governor and garrison of occupation from Genoa and Doria's militaryeconomic alliance with the Hapsburg Holy Roman Emperor Charles V. ${ }^{21}$ Under Andrea Doria (1466-1560), who assumed (from Suetonius) the political guise and role of "Augustan founder and restorer of the "ancient' republic," the Genoese old nobility took control and reformed the communal government, based on a fragile unione of the Doria, Spinola, Fieschi, Grimaldi, and other old noble families, inscribed in the famous Genoese Libro d'Oro. ${ }^{22}$ These wary allies banned the Fregoso and Adorno from office and recast the new government in their own sumptuous, regal image, led by a biennial doge, five censors (headed by Andrea Doria as "supreme sindacator" in overseeing the constitution), eight governors of the senate (for judicial and political affairs), eight procurators (economic-fiscal affairs), a minor council of one hundred, drawn from a major council of four hundred nobles (the legislative base). Supporting this system were twentyeight alberghi neighborhoods, into which Genoa was consolidated from its previous sixty-four alberghi during the fifteenth century, each controlled by a local old noble family. ${ }^{23}$

In 1549-51, a group of old nobles petitioned the senate of the republic to clear a monumental street on the northern edge of the city, just inside the city walls at the top of the Valletta di Soziglia on Montalbano, directly above the port, for the construction of private palaces (Figs. 8-12). ${ }^{24}$ The chosen site was both symbolic and significant. Height meant status, and this lofty region echoed with historic meaning for the Genoese. Just above the site for the Strada Nuova were the

16. Early descriptions, emphasizing these family tower-precincts, are gathered in Giovanna Petti Balbi, Genowa medievale, vista dai contemporanei, Genoa, 1978. Urban views, highlighting these tower societies, are caralogued in Ennio Poleggi, Iconografia di Genoua e delle niviere, Genoa, 1977.

17. By the 15 th century, there were some 33 defensive towers and 135 porticoes (portiri) around which these old noble family groups gathered within the densely populated and built-up fabric of the late medieval city. See Poleggi, 19.

18. On the opposition between the old and new nobility, the landed and entrepreneurial classes of Genoa, see Heers (as in n. 15), 511-62; and Epstein (as in 11. 15), passim.

19. For contemporary political trends in Italy, comparing Genoa and other city-states, see Lauro Martines, Pouter and Imagination: City-States in Renaissanre ltak, New York, 1979.

20. On the indirect role of the old nobility in relation to the official Fregoso and Adorno family groups, during this period of Genoese political decline from the late 14th through the early 16 th centuries, see Francesco Guicciardini, Storia d Thalin, 1, ed. Franco Catalano, Rome, 1975, bk. 7, pt. 5: Heers (as in n. 15), 563-61 I; Teofilo De Negri, Storia di Genowa, Milan, 1974, 451-654; and Epstein (as in n. 15), 271-318.

21. For Andrea Doria's expulsion of the French and his foundation of the Genoese aristocratic republic, based on his extraordinarily broad military contract with Charles V as admiral of the Hapsburg Mediterranean fleet, see Lorenzo Capelloni, Vila del Principe Andrea Doria (1565). 2d ed., Genoa, 1863. 51-55; Carlo Sigonio, De vita et rebus gestis Andrede Auriae Melphiae Principis Lilmo duo, Genoa, 1586, bk. 1, chaps. 13-14; and Edoardo Grendi. "Andrea Doria, uomo del Rinascimento," in Grendi (as in n. 2), 139-72.

22. On Andrea Doria's "Augustan" iconography and the Genoese republic of 1528, see Elena Parma Armani, Perin del Vaun, Tomellin mancante, Genoa, 1986, chap. 6: Piero Boccardo, Andrea Doria e le arti, committemza e mecenatismo a Genowa nel Rinasrimentio, Rome, 1989, chaps. 2-5, 7-8; George L. Gorse, "Between Empire and Republic: Triumphal Entries into Genoa during the Sixteenth Century," in "All the wortd's a slage. .". Art and Pageantry in the Renaissance and Baroque, 1, ed. Barbara Wisch and Susan Munshower, University Park, Pa., 1990, 189-256; and (applied to the Mediterranean Sea) George L. ruins of the Castelletto (Fig. 9), the twelfth-century fortress tower standing over the city, which had been enlarged and refortified in 1401 with four round corner bastions by the French viceroy Jean le Meingre, maréchal de Boucicaut (1402-9), as part of his sweeping governmental and economic reforms during the early period of French occupation in Genoa. ${ }^{25}$ To the Genoese, the Castelletto was a symbol of foreign domination and tyranny. When Admiral Andrea Doria finally led the city in revolt against the French in September 1528, thus throwing "the barbarians" out of the city and "refounding" the "ancient" republic, the Castelletto was torn down and never rebuilt. ${ }^{26}$ The Strada Nuova transformed this closed, hilltop fortress of tyranny into an open, lustrous symbol of regained aristocratic republican "liberty" (Figs. 9 and 12).

Just above the Surada Nuova stood the major thirteenthcentury Gothic Latin-cross church of S. Francesco di Castelletto (Figs. 11, 12), decorated in rich, bright black and white marble. This mendicant church, with S. Domenico to the south, ministered to the spiritual and temporal needs of the faithful who lived beyond the zone of the cathedral and the doge's palace. ${ }^{27}$ Noble families that lived in this area, including the Grimaldi, de Fornari, Lomellini, and Spinola di Luccoli, had family chapels in S. Francesco di Castelletto and other ties to the church. ${ }^{28}$ To the east of the Strada Nuova opened the small Piazza del Fonte Moroso (Fig. 17), into which the northern city gate of Portello opened, which was later enlarged as the center of the Spinola di Luccoli and Pallavicino family quarters. ${ }^{29}$ To the south on the steep hillside was the contrada di S. Maddalena, a poor district, anchored by the parish church of that name, where the main attraction was the public brothel (il postribolo pubblico). ${ }^{30}$

The prominence of the hillside site, its accessibility yet

Gorse, "Committenza e ambiente alla 'corte' di Andrea Doria a Genova," in Arte, commiltenza ed economia a Roma e nelle corti del Rinasrimento $(1420-1530)$, ed. Arnold Esch and Christoph Frommel. Turin, 1995, 255-71. For this aristocratic constitutional reform and restrictive ledger (Libro dOro) of old noble families who could hold political office and power, influenced as it was by the Venetian patrician republic, see Costantini (as in n. 2), 19-36; Savelli (as in 11 . 2), 39-79.

23. See Jacques Heers, Genowa nel Quathrocentio, Milan, 1984, 335-41, for the more decentralized albergo system of the 15 th century; and Edoardo Grendi, "Le conventicole nobiliari e la Riforma del 1528." in Grendi (as in n. 2), 105-38, for the consolidated albergo system of Andrea Doria's republic, which enforced old noble, local control.

24. For Cristoforo de Grassi's bird's-eve view of Genoa of 1597, based on an earlier view of the city in 1481, which shows the previous condition of this site with the Castelletto and ramparts (discussed below), see Poleggi (as in n. 16), $110-13$, no. 58 . In nos. 38-54, 74-103, Poleggi visually chronicles the 16th-to 18 th-century transformations, from closed fortress to open residential district. 25. De Negri (as in n. 20), 507-42.

26. Capelloni (as in л. 21), 53-57; Sigonio (as in n. 21), bk. 1, chap. 14; Grendi (as in n. 2), 139-72.

27. For the view of Genoa by Gerolamo Bordoni of 1616 , showing this area in detail, see Poleggi (as in 11. 16), 116-21, no. 62.

28. For a detailed study of the church, see Giorgio Rossini, "San Francesco di Castelletto: Dagli inizi alle demolizioni ottocentesche," in Giowanni Pisano a Genova, ed. Max Seidel, Genoa, 1987, 229-61. Recently, Mary Gibbons Weitzel (Giambologna: Nartator of the Catholic Reformation, Berkeley, Calif., 1995) discussed the 16th-century patronage of this church by the Grimaldi family, contemporary with the Strada Nuova.

29. See the reconstruction map of this area before 1414 with family concentrations of Grimaldi, di Fornari, Lomellini, and Spinola di Luccoli, in Grossi Bianchi and Poleggi (as in n. 13), 202-3, pl. xu.

30. Poleggi, 32. This public brothel was institutionalized with a guild and governor (podestai) for proper regulation and control in 1336. 
10 W. B. Clarke and B. R. Davies, General plan of Genoa, late 18th or early 19th century. London: Charles Knight \& Co. (photo: Collection of George L. Gorse)

11 Gerolamo Bordoni, Bird's-eye View of Genoa. 1616. Genoa, Ludovico Pallavicino Collection (from Poleggi, Iconografia di Genova e delle riviere, fig. 70)

remoteness on the northern edge of the medieval city, as a peripheral and largely abandoned and uncontested space, made the Castelletto area particularly attractive for urban development. According to a census in 1530, Genoa had a population of 51,150 . By 1570 , this number had grown to 70,000 , largely owing to the relative stability and prosperity of the new republic. ${ }^{31}$ Much of the population was concentrated along the medieval harbor front, the traditional focus of economic and political activity, and this rapidly increasing density was a major factor in the new expansion into the hills. During the $1530 \mathrm{~s}$ and $1540 \mathrm{~s}$, the republic began a series of ambitious urban projects to modernize and expand the darsena (arsenal) and ripa (harbor front) market porticoes (Figs. 8, 11), Genoa's major urban space, as well as to create an interconnected sequence of "modern" public piazzas- pockets of light, air, and circulation within the dense medieval urban forest, just one street in from the waterfront-along the major thoroughfares from the western city gate of $\mathrm{S}$. Tomaso to Fossatello; the three central port marketplaces of Banchi, Soziglia, and S. Giorgio; S. Lorenzo (the cathedral and archbishop's palace); and Ferraria (now Piazza Matteotti, the public square in front of the doge's palace). These served the vital social, economic, political, religious, and ceremonial needs of the renewed patrician regime. ${ }^{32}$ As part of this re-creation of public space, the signoria (communal government) began in 1535 to rebuild the entire circuit of city walls, first laid out in 1346-47, replacing the medieval circular corner bastions with Renaissance diamond-shaped ones, following the latest military technology. ${ }^{33}$ This reinforcement did not anticipate the impending population explosion of the 
1530 s through $1560 \mathrm{~s}$, and Genoa did not see a significant change in its city limits until the dramatic Baroque expansion to the very crest of the encircling mountains in 1626-36 (Figs. $10,11) \cdot 34$

The Strada Nuova was a key part-a new highland phase - of the Genoese republic's extensive urban program of the 1530 s and $1540 \mathrm{~s}{ }^{35}$ On March 17, 1550, the signoria had completed its study of the petition by old noble families, and it issued a decree approving a report by the patres communis, the magistracy of five nobles elected to supervise urban planning, stating the feasibility of new construction on the site of the postribolo pubblico. ${ }^{36}$ The signoria placed the padri del comune in charge of technical and financial aspects of the project, to be overseen by seven elected depulati (deputies) from the old nobility. A second, fundamental proclamation by the signoria on January 22, 1551, declared that taxes and income from the sale of lots on the Strada Nuova were to be used in support of the cathedral at S. Lorenzo, where a new high, templelike classical dome and tribune were constructed after 1550 by the Perugian-Roman architect Galeazzo Alessi. ${ }^{37}$ This integral linkage between the Strada Nuova and the cathedral again points to the creative interchange between private-to-public interests in the Genoese republic, and it further supports the traditional attribution of the Strada Nuova to Galeazzo Alessi.

Shortly thereafter, on March 13, 1551, the signoria authorized the transfer of the postribolo pubblico from the Contrada di S. Maddalena to the ruins of the Castelletto, effectively converting this bastion of Mars into one of Venus. ${ }^{38}$ The brothel and a hostelry and tavern were rebuilt right inside the fortress ruins. ${ }^{39}$ Thus began a rapid and extensive series of confiscations and demolitions in the contrada di S. Maddalena to prepare for surveying, laying out, and excavating the Strada Nuova along the slope of Montalbano. ${ }^{40}$ Expropriations in the area included some thirty-eight houses (among these, four large houses), twenty-two small urban gardens, a dye works, a public square, and a courtyard for ball playing, for the most part occupied by the poorer classes (popoli minuti) in this marginal popular quarter (quartiere popolare) that were acquired by the commune for just under 80,000 lire genovesi. The original ten lots on the Strada Nuova were then sold for just over 115,000 lire, producing a handsome profit for the cathedral works. ${ }^{41}$

However, these preparations were not unopposed by prominent local citizens and the friars of S. Francesco. Gerolamo

31. Giuseppe Felloni, "Popolazione e case a Genova nel 1531-35," Alti della Societia Ligure di Storia Patria, n.s. 4. L.xxvII, fasc. 2. Julv-Dec. 1964, cited in Poleggi, 50.

32. For these urban commissions, see Poleggi, 45-65. On some of the ceremonial occasions that this urbanism served, see Gorse, 1990 (as in n. 22), $189-256$.

33. This project was undertaken by the military architect to Emperor Charles V, Giovanni Maria Olgiati, another indication of major Hapsburg interest in the stability of the Genoese republic. For this project, see Poleggi, $18,28,50,78$ ก. 22

34. Poleggi and Cevini (as in n. 13), 129-41

35. Poleggi, $45-65$.

36. This procedure was twpical of Genoese urban planning since the late Middle Ages, Petitions from individual citizens or family groups to the serrate were considered and, if approved, then placed in the hands of the patres communis, Genoa s version of the mastri di strate in charge of urban planning and sanitation, regulation, and enforcement.
12 Detail of Fig. 11 showing the Strada Nuova with the ruins of the Castelletto, gardens, and S. Francesco above (from Caraceni, A Renaissance Street: Via Garibaldi in Genoa, 17)

Spinola, a neighbor, approached the signoria with three other signatories from his family clan, posing the charge that:

Although many have said that this street is being made for the beauty of the city, we doubt that this is so. Instead, it is to please five or six citizens who for their own comfort [the signoria and paires communis] are trying to accommodate these few for frivolous reasons, without regard to the damage and discomfort of those who live in these sites. And if the goal is to make beautiful and clean streets, many other places in the city would prove more useful to those in need rather than proceeding in the location where you are trying to build this street. ${ }^{42}$

The need for this street, claimed by the signoria and padri del comune "for the beauty of the city," was not clear to many others (particularly those displaced, taxed, or simply left out), who saw that it would benefit only a few chosen "cittadini" whose huge palaces were to dominate the new, fashionable

37. Poleggi, 451-52, doc. 2. Galeazzo Alessi is documented as the designet of the new cupola di S. Lorenzo, ca. 1550, while the executant architect on this project was the Lombard master (maestro antelamo) Antonio Roderio: see Emmina De Negri, Galearzo Alessi, Genoa, 1974; and ns. 66-68 below.

38. Poleggi, $452-58$, doc 4

39. Thid. 456 , dor 9.

40. Ibid. 27-33, 452-57, docs, 9, 4, 8, 10

41. Ibid., 32 , pls. 3, 4, tables A-C: Doria, 10-11.

42. "Anchor che molti habbino detto che essa strada si fa per bellesa della cit tà assai dubitiamo che cossi nom sia, anci sia per compiacere a cinque o sei cittadini quali per loro comodo con frivole ragioni cerchano di acomodarsi. senza haver risguardo al danno e discomodo di coloro de cui sono essi siti. $\mathrm{E}$ sel si volessi atendere a far belle strade e purirle, vi sariano in la città di molti luoghi e piü di quello che segue nel tocho dove si tenta fabricare essa strada." For the entire nemorandum, addressed "to the most serene Doge and very magnificent signori and procurators" of the Genoese republic, see Poleggi. $453-54$, doc. 5, March 17, 1551 . 
13 Galeazzo Alessi, Villa Giustiniani, Albaro, ca. 1550 (from Robert Reinhardt, Palast-Architektur von Ober-Italien und Toscana yom XV. bis XVI. Jahrhundert: Genua, Berlin, 1886, pl. 26)

urban quarter. ${ }^{43}$ The complaint of the friars of $\mathrm{S}$. Francesco di Castelletto, who were also alarmed, focused more on the relocation of the brothel than the clearing of the new street. They objected from a moral perspective to the "malavita $\mathrm{e}$ rofiani" (low life and ruffians) that such a public institution would bring to their church and to the neighborhood on its northern flank. ${ }^{4}$

This was to no avail. The patres communis pressed forward with preparatory work on the Strada Nuova after 1550-51, transferring the brothel, completing the confiscations and demolitions, clearing the site, surveying the central corridor of the street, dividing up and balancing the flanking building lots, excavating the earth and preparing the building platforms, determining the general building requirements, constructing the system of aqueducts, setting regulations for the construction sites, and auctioning off the high-priced lots to the restricted group of old noble petitioners in the area that ran from the garden wall of Luca Grimaldi on the west, below
S. Francesco di Castelletto, to the Piazza del Fonte Moroso on the east, near Portello (Figs. 12, 17, 21).45

During the next thirty-one years, from 1558-at the end of Genoa's war with France over Corsica, when economic conditions became favorable-until 1591, when the final street pavement was laid, ten family palaces were built in classical revival styles, aligned on opposite sides of the central triumphal way. ${ }^{16}$ To commemorate and promote the beginning of construction, the signoria designated the official name Strada Maggiore on April 21, 1558, although later documents and popular usage retained the name Strada Nuova. ${ }^{47}$ Contemporaries, such as the Genoese chronicler Giovanni Cibo Recco, used yet another appellation, the Via Aurea, a deliberately metaphorical reference to the "golden" ideal, meant to represent the character of this monumental, luminous, and aristocratic republican urban space, in contrast with the dark shadows and factious dangers of the medieval streets. ${ }^{48}$

Although ostensibly a public commission, the first ten palaces on the Strada Nuova were built by only five leading old noble families- the Spinola di Luccoli (four), Pallavicino (two), Lomellino (two), Grimaldi (one), and Lercari (one)which suggests the very exclusive character of the street ("to please five or six citizens," as Gerolamo Spinola caustically noted in his letter to the signoria) and also the concentrated nature of power in Genoa during the mid-sixteenth century. Early published city plans and Gerolamo Bordoni's painted Bird's-Fye Vieu of Genoa of 1616 (Figs. 10, 11, 12) show the street in its prominent site with five palaces built into the nor thern hillside, their stepped, terraced gardens rising up to the city wall in back, and a second row of five palaces built over the sharp descent into the urban cavity below to the south with rear loggias, balcony platforms, and giardini pensili (hanging gardens), overlooking small piazzas and the harbor. ${ }^{49}$ From this south to north perspective, the Strada Nuova represents a radically three-dimensional projection into space, a series of dramatic ascending tiers, forming a boundary and bridge between town and country (urbs et rus)-a combined urban palace, street, and suburban villa district-reuniting their respective social and cultural worlds of negotium (poli-
43. Along with Gerolamo Spinola's letter of complaint, there were other petitions to the signoria with lists of signatories against the public confiscations and transfer of the prostribols putblice; see ibid. 459-55, docs, 5, 7. These include not only old noble families, such as the Spinola di Luccoli, Lomellini, and di Negro, who lived in the neighborhood, but members of the new nobility and merchant class as well.

44. For the full text of this document, see ibid., 454-5.5, doc. 6, dated 1551?

45. Ibid., 451-68, docs. 2-4, 8-12, 15, 17, 20.

46. Ibid., chaps. 5-15. Concern about the slow construction and drain on public finances during the Corsican War of 1552 to 1558 is reflected in document of April 27, 1556, announcing the sale of Strada Nuova lots in the Banchi ("under the portico of the house of Paolo Gentile"), which again defends the public benefit of the project against opposition raised by Gerolamo Spinola and orhers; see ibid., 456-57, doc. 10.

47. Ibid., 462, doc. 13, April 21, 1558: “. . . ipsa appelerure et denominetu strata magiore. ..." (itself called and named the major street).

48. Giovanni Cibo Recco provides an interesting account of the public expropriation and sale of Strada Nuova properties, in which he says that the value of the buildings and land next to the public brothel was estimated at up to 50,000 lire, and purchased for that price at public expense, while they were sold to their new palace builders for 100,000 lire per lot: " . . sulla piaza de mercanti genovesi [Banchi] ai cittadini più ricchi, che di poi fecero costruirc in quel luogo edifici regali che gli occhi di noi tutti oggi possono vedere. Ed un vicolo di tal fatta fu chiamato via aurea" (on the piazza of the Genoese merchants to the richest citizens. who will build in that place edifices more regal than we have ever seen, and a lane in that manner called the golden street). See Poleggi, 34-35.

49. Poleggi (as in n. 16), 116-21, no, 62.

50. For discussion of the classical notions of negotium and olium, gleanecl from the writings of Cicero and Pliny the Younger, and their influence on Renaissance patrons and builders of palace and villa architecture, see James Ackerman, "Sources of the Renaissance Villa," in The Rirnaismnere and Mamnerism: Acts of the XXth Intemationat Congress of the Hislony of Art. It. Princeton, N.J., 1963, 6-19: B. Rupprecht, "Villa, zur Geschichte eines Ideal," in Probleme der Kunstwissteschaft, II, 1966, 210-50: David R. Coffin, The Villa in the Life of Renaissane Rome, Princeton. N.J., 1979, 9-22.

51. Poleggi, chap. 16.

52. Vasari includes Alessi in his "Life of Leone Leoni and Other Seulptors and Architects"; Giorgio Vasari, Le wite de piü exeltenti pithori, sculton ed architettor, vII, ed. Gaetano Milanesi, Florence, 1906, 553-55. Vasari's passage on the Strada Nuova (vH, 553) reads: "Il medesimo ha fatto la strada nuova di Genova con tanti palizzi fatti con suo disegno alla modema, che molti affermano in niun'altra città d'Italia trovarsi una strada più questa magnifica e grande, nè più ripiena di ricchissimi palazzi, stati fatti da quésignori a persuasione a con ordine di Galeazo; al quale confessano tutti avere obligo grandissimo, poichè è stato inventore ed esecutore d'opere che, quanto agli edifizi, rendono senza comparazione la loro citta molto più magnifica e grande ch' clla non cra" (The same [Alessi] made the new street in Genoa with many palaces designed by him in the modern style, which many affirm that in no other city in Italy does one find a street more magnificent and grand than this, nor more full of very rich palaces, made for these signori according to the 
tics, economics) and otium (contemplation, pleasure). ${ }^{50}$ Three more palaces of the Doria-Tursi and the new noble DurazzoBrignole-Sale family clans, the latter a strong indication of cives notes ascendancy, were added on the western end during the late seventeenth and early eighteenth centuries to make up the present complement of thirteen palaces from east to west. ${ }^{51}$

In the second edition of his famous Le vite de'più eccellenti pittori, scultori ed architettori, published in Florence in 1568 at an early stage of the street's construction, Giorgio Vasari already showed a critical appreciation of the Strada Nuova in the history of Italian Renaissance cities, by attributing its overall design to the Perugian-Roman architect Galeazzo Alessi, who worked in Genoa from 1548 to $1560 .^{52}$ Vasari discussed the Strada Nuova as part of a comprehensive urban plan for the renewal of Genoa by its prosperous mercantile aristocracy (Fig. 11). In his view the plan gave a specifically Roman classical image to the city, by means of such features as Alessi's monumental centralized domed church of S. Maria Assunta, modeled directly after the plans by Donato Bramante and Giuliano da Sangallo the Younger for new St. Peter's in Rome, constructed for the powerful Cardinal Sauli family in its ancestral neighborhood of Carignano on the southern promontory, overlooking the port entrance; the expansion and modernization of the entire city walls; the rebuilding and modernization of the waterfront, including Alessi's rustic molo (jetty) city gate; the enlargement of the crossing and tribune of the twelfth-century cathedral of S. Lorenzo, next to the Palazzo Ducale, topped by Alessi's Renaissance dome; and Alessi's construction of classical villas for the Pallavicino and Giustiniani families in the new Murtedo and Albaro suburbs (Figs. 11, 12, 13, 30). ${ }^{.3}$ Alessi's Villa Giustiniani-Cambiaso in Albaro (Fig. 13), for instance, was based in form and function upon the Roman Renaissance tradition of the classical villa suburbana, exemplified by the Vatican Villa Belvedere of the Genoese Pope Innocent VIII Cibo and Baldassare Peruzzi's Villa Farnesina for the Sienese banker to the Ligurian Pope Julius II della Rovere, Agostino Chigi, on the Tiber River. ${ }^{54}$

In this program of urban renovation, Alessi introduced a

conviction and order of Galeazo: to which all confess to have very great obligation. since he was the inventor and executor of these works, as much as these buildings, which render their city without comparison to be much more magnificent and grand than it ever was before).

53. For these commissions, see Vasari (as in n. 52), v11, 553-55; Lotz et al. (as in n. 5), 289-148; Emmina De Negri et al., Gateazon Alessi, Genoa, 1974, passim: Ludwig H. Heydenreich and Wolfgang Lotz. Architecture in ltaly 1400-1600, trans. Mary Hottinger, Baltimore, 1974, 287-91, cf. 214-15, 227-34, 313-15: Gary M. Radke, "Galeazoo Alessi," Marmillan Encyclopedia of Architects, I, ed. Adoll Placzek, London, 1982, 62-65.

54. Emmina De Negri et al., Catalogo delle ville genozesi, Borgo San Dalmazzo, 1967, 415-23, 100-117; Lauro Magnani, Il Tempio del Venere: Giardino evilla nella cultura genosese, Genoa, 1987. 59-80; and Salzer (as in n. 5). 44-118.

55. Unfortunately, there is no modern synthesis on Genoese ant and architecture to update Wilhelm Suida, Genua, Leipzig, 1906. For recent general studies of sculpture and painting, see Graviella Contiet al. I In sculturn a Genoza e in Liguria dalle origini al Cinquecento, 1, Genoa, 1987; Giuliana Algeri and Anna de Floriani, La pittura in Ligurin: Il Quattrocento, Genoa, 1992. For previous studies of Genoese palace and villa types and their basic developments, see Mario Labò, "Larchitettura dei palazzi genovesi," Lo Sprtlatore. Rivista di Lettere, Arti, Scienze, Politica, 1, no. 2, Feb. 1922, 141-51; idem, "Le ville genovesi," Emporium, LxxxvI, 1938, 131-44; Ennio Poleggi, "Genova e l'architettura di villa nel secolo XVI." Bollettino del Centro Internnsionale di Studi di Architeltura Andrea Palladio, Xt, 1969, 231-42; George L. Gorse, "Genoese Renaissance Villas: A Typological Introduction," Journal of Garden History. III. no. 4 , Oct.-Dec, $1983,255-80$.

56. On the Genoese alberghi and their historical foundations, see Ennio
Roman late Renaissance style of palace and villa architecture and street and fortification design into a city that had largely preserved its medieval character until the late fifteenth and early sixteenth centuries, when Renaissance innovations in architecture, painting, sculpture, and garden design began to be introduced. ${ }^{55}$ The characteristic form of urban settlement in late medieval Genoa, up until that time, had been the albergo-a closed, local neighborhood defined as a territory and centered inward on a major family piazza and church with palaces of the family clan gathered all around (Figs. 7, 8). ${ }^{56}$ The albergo, the urban focus of family patronage, gave relative stability to (while being a factor in the instability of) the medieval commune. A well-preserved example of a Genoese family square, center of an important albergo, is the thirteenth-century Piazza di S. Matteo of the Doria family, which controlled access to the northern city gates and the surrounding neighborhood from an enclosed and highly defensible urban enclave (Figs. 7, 14, 15). ${ }^{57}$ Perhaps the very stability and persistence of the Genoese albergo-twenty-eight alberghi were recognized officially as legal, judicial, social, economic, political, religious, architectural, territorial, and administrative units with the foundation of Andrea Doria's aristocratic republic in 1528 - had been a factor in the city's resistance to Renaissance culture up until the mid-sixteenth century. ${ }^{58}$

What changed in the mid-sixteenth century to bring together five noble families in the Strada Nuova that had lived in separate medieval quarters or in separate villa groupings, and made them choose a Roman style of architecture and decoration, was undoubtedly their new situation in the ideology and politics of the refounded republic. During the first half of the sixteenth century, humanists in the service of Andrea Doria's republican government rhetorically represented Genoa as a "New Athens," a "New Rome"-reliving a "Golden Age," exceeding even that of the medieval republic, that played on the founder's name (D'oria=d'oro) and his leadership of the old nobility (patrizio=patria) -in their public writings and oratory. ${ }^{59}$ Paolo Francesco Partenopeo, the official historian and orator of the republic during the

Poleggi, "Le contrade delle consorterie nobiliari a Genova tra il XII e il XIII secolo," Urbanistixa, XIII-XI.II, 1964, 15-20; Jacques Heers, Le dan familial an Moyen Agf: Etude sur les struclures folitiques at sociales des milinax usbains. Paris, 1974: Diane W. Hughes. "Lrban Growth and Family Structure in Medieval Genoa," Past and Present, 1.xv1, 1975, 3-28; Edoardo Grendi, "Profilo storico degli Alberghi genovesi," in Grendi (as in n. 2), 49-102; and Epstein (as in n. 15), 153-54,232-33 and passim

57. Jacopo Doria, La chiesa di San Matteo in Genova, Genoa, 1860; Paolo Montano, "La piazza, la chiesa e il chiostro di San Matteo," Ouademo, no. 4 1970, 167-99; Jacques Heers. "Urbanisme et structure sociale â Gênes au Moyen-Age," in Sociêté at économie à Gênes (XTV-XVé siêcles), London, 1979. chap. 11. 371-412; George L. Gorse, "A Family Enclave in Medieval Genoa," fournal of Arhitectural Education, Xu.11, no, 3, Spring 1988, 20-24.

58. On the twenty-eight allerghias the foundation for the Genoese "reform" of 1528 , see Grendi, "Un esempio di arcaismo politico," in Grendi (as in n. 2), 948-68: Savelli (as in n. 2), 39-79; Costantini (as in n. 2), 19-36.

59. The humanist model for this Genoese propaganda was Suetonius's Life of Augustus and the cult of the "Golden Age" in Augustan Rome. For a discussion of this political mythmaking, see Paul Zanker. The Power of Images in the Age of Augustus, trans. Alan Shapiro, Ann Arbor, Mich.. 1990, 167ff. Andrea Doria sponsored this Augustan "Golden Age" image of himself and the republic, following the Medici model from 15 th-century Florence, including the official title of Pater Patriae, given posthumously to Cosimo de "Medici i Vecchio. See Ernst H. Gombrich, "Renaissance and Golden Age," in Norm and Form: Studies in the Ant of the Renaissance, London, 1971, 29-34; Alison Brown. "The Humanist Portrait of Cosimo de" Medici, Pater Patriae," Journal of the Watiurg and Courtauld Institutes, xxrV, 1961, 186-214. 
14 13th-century Doria family piazza of S. Matteo (photo: Archivio Fotografico del Comune di Genova)

$1530 \mathrm{~s}$ and $1540 \mathrm{~s}$, specifically made these highly charged, political analogies in his series of Orationes and classically inspired Annali della repubblica. ${ }^{60}$ Ludovico Spinola, another Genoese humanist, wrote a treatise during the 1540s on the republican institutions of Genoa. His justification of aristocratic rule was based on Plato's Republic (and the analogy between the state and the human body, the head being the "Philosopher King," or leader of the aristocracy) and Aristotle's Politics (which recommends oligarchy as the ideal "golden mean" among the three forms of government, over monarchy/tyranny and government by the people, demos, democracy, disorder). ${ }^{61}$ The Alessian classical style of the Strada Nuova presented the solemn Romanitas and Augustan Golden Age ideology and politics of this humanist rhetoric.

In reality, the republic of 1528 succeeded in reinvigorating the social and political order of Genoa by cementing its economic ties with the Hapsburg Empire, by freeing it from direct outside French, Milanese, Piedmontese, or Spanish control, and by enforcing relative internal peace among rival old noble families and among these, the new nobility, the middle-class merchants, and the artisan-working classes. ${ }^{62}$ Contemporary Genoese chroniclers and historians, even the

60. See Annati di Paolo Partenopeo voltati dalla Latina nell Tatiana favella da Stefano Bacigalupo (1536). Genoa, 1847, xi-xx; "Oratio Pauli Fr. Parthenopaei de tranquillitate Reipu. e eius conservatione ad illustrissimum Senatum Genuensem habito Anno domini. MDXXXVIII. pridie Idus Septembreis." 1538, 1589, 1540, Genoa, Biblioteca della Universitâ di Genova, Rari x. 58. 1,2, 3. For Genoese civic humanism, see Paul Oskar Kristeller, Iter Italirum, 1. London, 1963, 237-48: Eric Cochrane, Historians and Historiography in the Itatian Renaissana, Chicago, 1981, 74-77; Gian Giacomo Musso, La cultura genovese nelletai dell'umanesimo, Genoa, 1985, 7-110.

61. Ludovici Spinulae, "De reipublicae institutione ad Andream Auriam P.P." Genoa, Biblioteca della Università di Genova. MS. B.1.15. 4v-8v. For this Genoese humanist, with a transcription of his treatise from a manuscript in Modena, Biblioteca Fstense, see Silvana Seidel Menchi, "Passione civile c ancliti Erasmiani di riforma nel patriziato genovese del primo Cinquecento: Ludovico Spinola," Rinascimento, 2d ser., xvII, Florence, 1978, 87-134.

62. There were a lot of threats against this delicate "unione," most famous of which was the conspiracy of Luigi Fieschi against Andrea Doria and the
Florentine writers Niccolò Machiavelli and Francesco Guicciardini, stressed the endemic problem of family faction, violence, vendetta, and division in late medieval Genoa and the weakness of centralized, communal authority before the sixteenth century. ${ }^{63}$ The compartmentalized, protected, insular world of the Genoese albergo was the one relatively still eye in the medieval urban hurricane, a haven from and base for private family power, a social order rooted in private family cohesion and violence toward other family groups (Figs. 6, 7, $8,14,15)$. The relative stability of the Genoese republic of 1528 , with its motto "Unione e Libertà," tended to open up these medieval enclaves to more citywide concerns (Figs. 11, 12). The Doria republic of 1528 was fashioned by the old nobility, members of the titled aristocracy of the once feudal but now landed military, merchant, and banking class whose names were inscribed in the Libro d'Oro, the "Golden Book" of the republic, which guaranteed their political power through restrictions of eligibility for office to this group. ${ }^{64}$ But during the third quarter of the sixteenth century, from the unsuccessful conspiracy of the Fieschi family against Andrea Doria and his government in 1547 to the revolt of the new nobility and its further reform of the republic in 1575-76,

republic in 1547: see Jacopo Bonfadio. Annali delle cose de genozesi dall anno 1528 simo allimne 1550, Capolago, 1836, 145-74; Capelloni (as in n. 21). 131-50; Sigonio (as in n. 21), bk. 2, chap. 30) and Kate McCluer, "A Newly Discovered Last Will and Testament of Andrea Doria." Rinasrimento, $2 \mathrm{~d}$ ser. xxxIII, 1995, 125-12.

63. Niccolo Machiavelli. Istorie forentiue, ed. Ftanco Gacta, Milan, 1962, bk. 5. pt, 6, 335tf, Guicciardini (as in n, 20), bk, 7, 5; Agostino Giustiniani, Amat della Reprobblica di Genova, 1537, Bologna, 1981, passim; Jacopo Bonfadio (as in n. 62), passim.

64. For this constitutional-political system, see Vito Piergiovanni, "Il Senato della Repubblica di Genova nella "riforma' di Andrea Doria, Annali delle Facollâ di Gizurisprudenza, Genoa, Universitả degli Sudi, 1v, 1965, 230-75.

65. For this crucial period of $1547-75 / 76$, see Savelli (as in 0.2 ), chap. 3, "T nobili nuovi al potere: Tra dibattito e guerra." $81-152$; Costantini (as in n. 2). $37-18,89-122$

66. Mario Labô (403-10) maintained the traditional attribution of the Strada Nuova to Alessi, arguing that Bernardino Cantone, the architetto 
which included many of them in the Libro d'Oro, the old aristocracy was losing its grip on the republic. ${ }^{65}$ It was precisely during this period from the 1550 s through the 1580 s that the Strada Nuova was constructed by families belonging to the old nobility, at a time when their control over the republic was being challenged.

In this sense, the Strada Nuova was not so different from the medieval albergo, a closed grouping of family palaces on a common urban space for mutual protection and display. This collective family ensemble was paramount for social representation. Modern scholarship on the Strada Nuova has focused on the question of Vasari's attribution of its design to Alessi rather than on its political function as a classical stage for the old nobility. ${ }^{66}$ In a fundamental article of 1956, the Genoese scholar Mario Labò agreed with Vasari's attribution and related the street to Bramante's Via Giulia in Rome (Fig. 16), which was commissioned by the Ligurian Pope Julius II della Rovere in about 1510 , and was thus familiar to Alessi from his Perugian-Roman background. ${ }^{67}$ Alessi himself had designed a Bramantean axial street lined with classical palaces, the Via Nuova (now Via Mazzini), in his native Perugia, before coming to Genoa in $1548 .{ }^{68}$ However, it was Labò who first recognized that the Strada Nuova was more than a fully realized version of Bramante's unfinished Via Giulia. ${ }^{69}$ In the subtitle of his paper, Labò called the Strada Nuova "più che una strada, un quartiere" (more than a street, a neighborhood) to distinguish the Roman origins of the Strada Nuova design from its function in Genoa as an enclosed urban family space. ${ }^{70}$ For, as Labò pointed out, the Strada Nuova originally was closed at its west end by a wall and garden owned by Luca Grimaldi behind a narrow walking street (salita), ascending at right angles from the medieval port city below to the mendicant church of S. Francesco di Castelletto on the hill above. Both the Bordoni bird's-eye view of 1616 (Fig. 12) and a patres communis plan from the seventeenth century (Fig. 17) show the original urban concept of this "Renaissance street" as a closed, dead end. ${ }^{71}$

Alessi's plan terminated the Strada Nuova in a rustic grotto fountain on the outside wall of the Grimaldi garden at the west end, establishing a vanishing point for the entire street. ${ }^{72}$ On the east, the Strada Nuova emptied directly into the Piazza del Fonte Moroso, named after a surging fountain located in the square, from which a system of aqueducts fed the palaces.
15 Plan of Doria family neighborhood of S. Matteo (from Jacques Heers, Parties and Political Life in the Medieval West, Amsterdam, 1977, fig. 2)

This piazza did not have major street access; instead, it was surrounded by Pallavicino and Spinola family palaces. Thus, the purpose of the Strada Nuova, as Labò showed, was not to serve as a strada di transito, a thoroughfare between two major urban points, unlike Bramante's Via Giulia, which connected the Ponte Sisto and Trastevere to the Borgo dei Banchi with a ceremonial entryway (and a projected bridge) across the Tiber into the Borgo Vaticano. ${ }^{73}$ While Bramantean in style, the Strada Nuova was thoroughly Genoese in function: it served as a closed family neighborhood, a residential quarter, and a ceremonial stage for the self-representation of the elite group of families who built their palaces along it. I would thus call the Strada Nuova "a linear piazza," precisely because of camerale (administrative architect) of the padri del comune, had only an executive role in the project. However, Ennio Poleggi (chap. 4, "Gli autori di Strada Nuova," 67-79) has argued for the attribution of the Strada Nuova to Cantone, based on the lack of Alessi documents related to the street and the abundance of documents on Cantone as maestro di camera (master of the office) of the patres communis. However, the institutional connection between the Strada Nuova and the cathedral of S. Lorenzo, where Alessi is indeed documented as the designer over the executant architect, Antonio Roderio, supports the Alessi aturibution for the Strada Nuova. The coincidence and centrality of the Strada Nuova to other extensive, documented urban projects by Alessi in Genoa cannot be ignored.

67. Labo, 406

68. Lotz et al. (as in n. 5), 193-228 and passim; Radke (as in n. 53), 63.

69. Labò, 406 .

70. Ibid., 403,409

71. Labo, 406; and for the patres communis plan, see Poleggi, 48-61, $178 \mathrm{n}$. 26, pl. 10 .
72. Charles Burroughs pointed out to me that Bramante's Via Giulia also closed the street perspective in a grotto, at the south end near Ponte Sisto. However, the Via Giulia still functioned as a strada di transito-(transit street) into Trastevere, while the Strada Nuova was much more closed at its west end, with only the narrow and steep walkway to $\mathrm{S}$. Francesco di Castelletto at right angles to it. Cf. Luigi Salerno et al., Via Giulia, una utopia urbanistica del Cinquecento, Romc, 1973.

73. Labò, 406. Even Vasari's description of Bramante's Via Giulia suggests the more functional character of this representational, axial, circulation, and papal administration space; see Vasari (as in n. 52), IV, 159: "Si risolvè il papa di mettere di strada Giulia, da Bramante indrizzata, tutti gli ufficj e le ragioni di Roma in un luogo, per la commodità ch'ai negoziatori averia recato nelle faccende, essendo continuamente fino allora state molto scomode" (The pope [Julius II] resolved to direct Bramante to make the Via Giulia, in order to gather together in one place all the offices and agencies of Rome, for the convenience of all petitioners in their affairs, being until then inconvenienced continuously). 
16 16th-century axial plan of Rome, showing Bramante's Via Giulia (no. 2) through Sixtus V's Counter-Reformation city (from Heydenreich and Lotz, Architecture in Italy 1400 to $\mathrm{I600,}$ fig. 92)

its self-enclosed, self-contained, and self-reflective aristocratic character.

One might compare the Strada Nuova to Vasari's contemporary, nonresidential Uffizi in Florence of 1560-80. (Fig. 18), built for Cosimo I de' Medici as another linear; ceremonial space for the representation of ducal government, connecting the Palazzo Vecchio and Piazza Signoria to the Arno, the Corridoio, Palazzo Pitti, Via Maggio, and Via Tornabuoni in Florence. ${ }^{74}$ It also has correspondences with market squares (such as the Piazza delle Erbe in Verona, on the site of the ancient Roman forum), which were like the Strada Nuova in their longitudinal, hippodromelike shapes, although they had a more utilitarian, economic function. ${ }^{75}$ During the Renaissance and Baroque periods, the Piazza Navona in Rome, built on the ancient foundations and ruins of Emperor Domitian's hippodrome stadium, functioned as an analogous linear piazza space. It served as a showplace in Rome for, among others, the Medici family, which had palaces there during the fifteenth and sixteenth centuries, and later for the Pamphily family, whose palace, church, and theatrical Ba- roque fountains by Bernini and others transformed this ceremonial space into a royal precinct during the seventeenth and eighteenth centuries. ${ }^{76}$

The ceremonial uses of such enclosed spaces during the Renaissance and Baroque eras also resemble the festivities of the Strada Nuova in Genoa. A painting by an unknown Genoese artist in a private collection shows a Carnival Procession and Joust in the Piazza del Fonte Moroso and Strada Nuova (Figs. 19, 20), an image that corresponds to typical Genoese chronicle descriptions of the period. In the foreground of the painting, soldiers and members of the nobility parade on horseback in front of a black horseman with a crown (a Turk?) on the piazza, while temporary seating has been set up (just as in a hippodrome stadium) on the Strada Nuova in the background to display the hand-to-hand combat of swordsmen on foot. ${ }^{77}$ In this view, the Strada Nuova was the Circus Maximus of Genoa, a ceremonial stage, heir to the Roman imperial tradition of palace front, hippodrome space, and harbor view architecture, including the palatium of Domitian in Rome, the palace of Diocletian in Split, and the Byzantine imperial palace-church-stadium complex in Constantinople. ${ }^{78}$ During festive occasions, the Strada Nuova, with its imposing classical facades, its upper-floor, piano nobile (noble story) balustraded box seats, its long axial space (about 250 meters long by $7^{1 / 2}$ meters wide), and its rustic garden fountain backdrop at the west end, was literally transformed into a classical Roman stage, a monumental statement about the reborn (Renaissance) republic, similar to Serlio's Vitruvian reconstruction of the tragic theater set (Fig. 2), a dramatic arena for the predominant social class and order. The Renaissance style and perspectival form of the Strada Nuova were in themselves symbolic of the "rebirth" of the res publica.

The new corporate group quickly made its presence felt. Hardly had the first four palaces on the east end of the Strada Nuova been completed, between 1558 and 1578, when visiting dignitaries began to reside there. ${ }^{79}$ On October 2, 1581, Cardinal Riario, the thirty-three-year-old papal legate to Spain, arrived in Genoa aboard Giovanni Andrea Doria's galleys (grandnephew of and heir to Andrea Doria) on his way back to Rome, and he was received at public expense in the palace of Agostino Pallavicino, the first residence on the northeast corner of the Strada Nuova. ${ }^{80}$ There, he was entertained and met with official representatives of the republic, before proceeding to the ducal palace for sensitive diplomatic meetings concerning Genoa and the Hapsburg
74. Giorgio Spini, ed., Architettura e politica da Cosimo I a Ferdinando I, Florence, 1976; Roger Grum, " 'Cosmos, the World of Cosimo': The Iconography of the Uffizi Facade," Ant Bulletin, IXxi, 1989, 237-53; idem and Leon Sarkowsi, "Letters," Ant Bulletin, Lxxu, 1990, 131-35; and Leon Satkowski, Giongio Vasari: Architect and Courtier, Princeton, N.J., 1993.

75. Lotz (as in n. 7), 74-139.

76. Christoph I. Frommel, Der Römische Palastbau der Hochrenaissance, Tübing en, 1973, 1, 12, 17-18, 23, 57, 65, 79; 11, 275; Howard Hibbard, Bemini, New York, 1976, 120-24; Ann Sutherland Hatris, "Bernini's Four Riters Fountain as Permanent Theatre," in Wisch and Munshower (as in n. 22), II, 488-516.

77. For this painted view, see Poleggi. I78 n. 26, 437 n. 4, pl. 293. It should be noted that the composition of the foreground procession in this painting is a direct quote from Perino del Vaga's vault frescoes in the vestibule of Andrea
Doria's villa in Fassolo (ca. 1529-30) representing The Triumphal Entry of the Roman Consul Aemilius Poulus, who (like Doria in 1528) liberated Genoa from the Franks (the French) in 181 B.c.

78. This monumental imperial palace-hippodrome-harbor tradition, in which the Strada Nuova can be placed, was first outlined by Karl M. Swoboda, Römische und Romanische Palaste: Eine Architekturgeschicfitliche Unterstechung, Vienna, 1924. For its influence on Renaissance architecture, see Ackerman (as in $n .50), 6-19$.

79. For a list of the many formal entries and receptions of foreign heads of state into Genoa during the second half of the 16 th and early 17 th centuries. see Doria, 9 n. 20; Gorse, 1990 (as in n. 22), 219-22. For more quotidian events and old noble rituals on the Strada Nuova, see the insightul contemporary chronicles Inventione di Giulio Pallavirino di somver futte le cose arcadule alli tempi 
17 Patres communis plan of Genoa, detail of Strada Nuova, 1656, showing closed street at west end and Piazza del Fonte Moroso to the east (from Poleggi, pl. 10)

Empire. Undoubtedly, Agostino Pallavicino's large share in the papal alum trade made his palace a congenial place for the cardinal. During the next generation, in the spring of 1592, the duke of Mantua, Vincenzo I Gonzaga, who held major loans from the Genoese merchant-bankers, was entertained in the same palace of Francesco Pallavicino, Agostino's son. ${ }^{81}$ And, on February 16, 1601, Cardinal Pietro Aldobrandini, the nephew of Pope Clement VIII, while returning from a papal legacy to negotiate an end to war between the French King Henry IV and the duke of Savoy, stopped in Genoa and was received by the republic in the palace of Enrico Salvago on the Strada Nuova. ${ }^{82}$

During the second half of the sixteenth century, exactly corresponding with the period of the Strada Nuova's construction, the communal government commissioned a set of official Books of Ceremony (Libri dei Ceremoniali) of the republic of Genoa, which formalized the government's ceremonial protocols for domestic inaugurations and celebrations, as well as foreign receptions. ${ }^{83}$ Major symbols of state and ritual order were defined and controlled by the republic for the biennial doge, the senate (procurators and governors), magistrates, and ambassadors, along with the processional routes and diplomatic conventions for foreign entries.
Each type of ceremony was ranked according to the dignity of the office or foreign personage received. To maintain and enforce these standards, a public master of ceremonies (maestro delle ceremonie), Hieronimo Bordoni, was appointed in $1588^{84}$ This institutionalization of state ritual and public office was part of a broader European development toward the aristocratization of society and government during the late Renaissance and Baroque. ${ }^{85}$

The Strada Nuova played a key role in this move toward consolidating aristocratic culture. The Libri dei Ceremoniali led to the distinction, called la sorte, between three grades of palaces for foreign visitors: prima classe was reserved for popes, emperors, kings, and cardinal legates; seconda classe for cardinals and nobles ("signori di qualitâ"); and terza classe for "signori di minor qualità" (merchants and ambassadors, and so on). ${ }^{86}$ Almost all of the Strada Nuova palaces were listed in the first category of private family reception areas for public use, a good reason for their contemporary selection by Rubens as images of Genoese nobility. This hierarchical compartmentalization of society made the formal language of architecture and decoration on the Strada Nuova particularly important to the representation of the republic (a corporate "L'état, c'est moi!"), identified with the old noble families, at suoi (1583-1589), ed. Edoardo Grendi, Genoa, 1975; and Andrea Sprnota scritli scelti, ed. Carlo Bitossi, Genoa, 1981.

80. Gorse, 1990 (as in n. 22), 220. For a biographical sketch of Giovanni Andrea Doria (1540-1606) with bibliography, see Rodolfo Savelli, "Doria, Giovanni Andrea," in Dizionario brografuo degli italiani, 41, Rome, 1992, 361-75.

81. See Poleggi, chap. 17, "Fortuna di Strada Nuova." 425-35; Doria, 18. Vincenzo I Gonzaga came back to Genoa in 1600 and 1607. In Vincenzo Gonzaga's entourage of 1607 was Peter Paul Rubens, who probably started the project of collecting drawings for the engraved views and plans of the Palazsi di Genova (Antwerp, 1622) at that time; Labò, "Il soggiorno del Rubens a Genova," in Labò (as in n. 5), 11-22. The ceremonial context of Rubens's 1607 visit to Genoa and its connection to the Strada Nuova as a presentation space undoubtedly influenced his later publication of this major example to northern European noble patrons.

82. Gorse, 1990 (as in म. 22), 221-22.

83. Luigi Volpicelli, "I libri dei ceremoniali della Repubblica di Genova," Sorietí Ligur di Stomia Patra, XI.Ix, fasc. 11, Genoa, 1921.

84. Ibid., 14-15.

85. C.F. Richard C. Trexler, The "Gibro Cermoninle" of the Fonentine Reproblic by Fronceseo Filarpte and Angelo Manfidi. Travaux d'Humanisme et Renaissance, OLXV, Geneva, 1978; idem. Public Iife in Renaissance Flowence, Ithaca, N.Y. 1980; and Edward Muir, Civic Ritual in Renaissance Venice, Princeton, N.J., 1981.

86. La sorte was defined and the specific palaces in each category listed in three senate proclamations of 1588,1599 , and 1614. These three decrees listed (respectively) 111, 120, and 96 "case" (houses). See Ennio Poleggi, "Un documento di cultura abitativa," Rubens e Genoura, 85-122; Doria, 9-12. 
18 Giorgio Vasari, Uffizi, Florence, 1560-74, with copy of Michelangelo's David (photo: Alinari/Art Resource, New York)

the highest levels of domestic and foreign relations, involving visiting popes, emperors, kings, cardinal legates, and their audiences.

From the east, the first six palaces, or the first three facing pairs (Figs. 1, 21, 22: nos. 1-2, 3-4, 5-6), were conceived urbanistically as a group. ${ }^{87}$ The lot sizes of the first two palaces (Figs. 21, 22: nos. I-2), those of Agostino Pallavicino and Pantaleo Spinola, were restricted in size by the converging city walls, piazza, and contrada (neighborhood) fabric. However, these first two facades match each other in height and width, forming a balanced pair. In the Genoese Alessian style of the Strada Nuova, each palace was conceived as a powerfully three-dimensional, classically articulated cube in space, uniform in ensemble from the main ceremonial viewing point in the piazza at the end of the urban perspective (Figs. 19, 23). The patres communis set down general guidelines, within which individual patrons distinguished themselves through the surface decoration and articulation of their building block. While the first palace pair initiated and anchored the urban perspective, the second two palaces (Figs. 21, 22: nos. 3-4), those of Franco Lercari and Tobia Pallavicino, were equal in height to the first two; however, the lot sizes of the second pair were wider than those of the first. This expanded width was equal to that of the third pair (Figs. 21, 22: nos. 5-6), of Angelo Giovanni Spinola and Giambattista Spinola; but this third pair raised its cornice height above that of the first four palaces. ${ }^{88}$ The result was an overlapping, scenographic relationship of palace facades-in width (Figs. 21, 22: nos. 1-2, $3-4-5-6$ ) and height (Fig. 21: nos. 1-2-3-4, 5-6-7-8/10-129)-creating the appearance of consistency through the manipulation of height and width in relation to distance from the viewer. The overall visual effect of the monumental one-point perspective of the Strada Nuova, as seen from the Piazza del Fonte Moroso (Figs. 1, 17, 19, 23), was foremost in Alessi's urban concept and patres communis plan.

This pictorial approach also applied to individual palaces in depth. From the facade, the portal entrance began an interior prospettiva into screened variations of a vestibule, atrium, and courtyard sequence to a garden in back (Figs. 22, 25). In this grammar of interior space, the staircase was the transitive conjunction. ${ }^{89}$ The Alessian building block, so compact and closed on the outside from the street, opened up-even exploded-on the inside through a series of related rooms connected by column screens, dense classical decoration, and monumental staircases. On the north side of the Strada Nuova, the ascending, stagelike progression of the Genoese Renaissance palace was the most dramatic, reaching a crescendo in the palace of Nicolo Grimaldi, whom contemporaries called "il Monarca" because of his great wealth and power, on the west end (Figs. 21, 22: nos. 9, 24, 25). ${ }^{90}$ The sequential definition of relationships between entrance facade, portal, vestibule, atrium, courtyard, garden, and staircase to upperfloor vestibule, loggia, chapel, public salone, private anticamera, camera, studiolo, guardaroba, and bagno was part of the public ceremonial role and aristocratic court manner of these old noble burgher patrons, as defined by the Libri dei Ceremoniali. ${ }^{91}$ By the late cinquecento, public ceremony shaped space-and space shaped public ceremony.

The Strada Nuova created a triumphal monument to an
87. Poleggi, chaps. 6, 8, 14, 7. Beyond the general urban scheme, the question of attribution of individual palaces to Genoese architects working in the Alessian style is a very vexed problem. In many cases, there is no specific mention of architect-designers' names in the construction documents. For the question of architectural attribution, see App. below, which gives a consensus summary of patrons, architects, artists, and chronology.

88. Note that the palace of Tobia Pallavicino (Fig. 21: no, 4) has an added third story from the 18th century, which effectively took it out of the first group and transferred it into the second group of four palaces in this scenographic ar rangement.

89. On the Genoese staircase and its relationship to Spanish Hapsburg architecture, see Catherine Wilkinson, "The Escorial and the Invention of the Imperial Staircase," Art Bulletin, INII, 1975, 65-90 (with bibliography); and, for a general study, Renate Schmale, "Treppenanlagen in Genueser Palasten des 16 Jahrhunderts: Materialien zu einer denkmalkundlichen, sozialgeschichtlichen und stilgeschichtlichen Klassifizierung," Ph.D. diss., Kiel, 1969.

90. On the Palazzo Grimaldi (now Palazzo del Municipio), see Poleggi, chap. $13,301-48$.

91. This major concern for ceremonial room function and sequence can be seen in the detailed ground plans (with carefully inscribed room functions) of Genoese palaces and villas throughout the Royal Institute of British Architects album of drawings for Peter Paul Rubens's Palazzi di Genovia of 1622 (see n. 5 above). For the development of integrated and differentiated apartments in Renaissance palaces, see Frommel (as in n. 76), 1, 1-93; Kathleen Weil-Garris and John D'Amico, "The Renaissance Cardinal's Ideal Palace: A Chapter from 
19 Artist unknown,

Camival Procession and Joust in the Piazza del Fonte Moroso and Strada Nuova, early

17 th century. Genoa,

Marchese Orso Serra

Collection (from Torriti,

Tesori di Strada Nuova, la Via

Aurea dei genovesi, fig. 10)

elite corporate group, and it spoke the visual language of the festive processions and celebrations that occurred within its boundaries. The interplay of facades on the Strada Nuova offered a sumptuous visual representation of the corporate clan, at once imposing and inviting. While visually retaining a distinct facade style, the palaces were related in urban plan. The Strada Nuova displayed four major palace facade styles. The first was the "rustic-pilaster-aedicular facade-type" of the palaces of Agostino and Tobia Pallavicino (Fig. 21: nos. 1, 4), which symbolically related these two brothers diagonally across the urban corridor. It was certainly no coincidence that the Pallavicino palaces were located at the east end of the Strada Nuova, next to the family albergo on the Piazza del Fonte Moroso (Figs. 12, 17). ${ }^{92}$ This albergo extension also applied to the four Spinola palaces, concentrated on the eastern half of the street, near their family neighborhood space in the piazza. ${ }^{93}$ Alessi's Renaissance perspective street did not break with but instead responded to medieval Genoese residential patterns.

Cortesi's De Cardinulatu," in Memoirs of the American Academy in Rome, 1, ed. Henry Millon, Rome, 1980, 45-123; and for changes in Roman Baroque palaces, see Patricia Waddy, Seventeenth-Century Roman Palaces: Use and the Art of the Plan, Cambridge, Mass., 1990.

92. The adjacent palace of Interiano Pallavicino on the Piazza del Fonte Moroso (no. 2), dated 1565, should also be considered as part of this family palace group. See Rubens, "Palazzo G," with six plates; and Guida d'talia: Liguria, Milan, 1982, 146

93. Cf. the Spinola Strada Nuova palaces with the transitional late medievalearly Renaissance black and white marble facade of the Palazzo Spinola "dei Marmi" of ca. 1450-75 at the east end of the Piazza del Fonte Moroso, in Gorse (as in n. 55), 256-59.
20 Detail of Fig. 19, showing the Strada Nuova and ceremonial joust 
21 Family palace facade interactions on the Strada Nuova by Via Garibaldi numbers; see App. for chronologies (photo: Archivio Fotografico del Comune di Genova)

22 General plan of Strada Nuova palaces

(corresponding to Fig. 21) with palace facade,

vestibule, atrium, courtyard, staircase, piano nobile sequence (photo: Archivio Fotografico del Comune di Genova)

23 Antonio Giolfi,

Perspective view of the Strada Nuova from the east, 1769. Genoa,

Collezione Topografica del Comune 
24 Giolfi, Facade view of palace of Nicolò Grimaldi with $\mathrm{S}$. Francesco in back (photo: Archivio Fotografico del Comune di Genova)

25 Domenico and Giovanni Ponzello, Interior courtyard of the palace of Nicolò Grimaldi, 1565-79 (from

Reinhardt, pl. 10)

The architectural dynamic of the palace of Agostino Pallavicino (Figs. 1, 26) was achieved by the vibrant chiaroscuro of "foreground" creamy white Carrara marble Doric pilasters, Ionic corbels, meander pattern moldings, lions' heads, a prominent family coat of arms within the Doric pedimental entrance portal, and strongly projecting aedicular window frames. These all'antica elements compete with the equally aggressive and richly textured rustic pilasters treated as if they were a large Doric order in the "background" interstices, carved in a deep, charcoal gray pietra di Promontorio from local quarries in Val Polcevera northwest of Genoa. ${ }^{94}$ The result is a

94. See Poleggi, chap, 6, 101-28

95. Cf. Howard Burns, "Le idee di Galeazzo Alessi sull architetura e sugli ordini," and Christoph Frommel. "Galeazzo Alessi e la tipologia del Palazzo rinascimentale," in Lote et al. (as in n. 5), 147-66, 167-71. For the Roman sources, see Frommel (as in n. 76), 3 vols,, passim; and for facade emblematics. see Charles Burroughs. "The Building's Face and the Herculean Paradigm lively, bichromatic interplay of gray and white, "natural" rustic and "artful" dressed stone, a pictorial facade architecture (transcribed into Rubens's engraved view) setting into motion the linear piazza. While Alessi based the Palazzo Pallavicino on Bramante's Palazzo Caprini in Rome (Fig. 27), he did not separate rustic base from smooth dressed stone and classical orders on the piano nobile, as Bramante did, but rather fused these elements together in tension within a Mannerist court style similar to the architecture of lateRaphael, Michelangelo, Giulio Romano, Palladio, and Michele Sanmicheli. ${ }^{95}$ All along the Strada Nuova, ground-floor insu-

Agendas and Agency in Roman Renaissance Architecture," Res 23, xxII Spring 1993, 7-30. And, for comparison with other regions, see Davic Friedman, "Palaces and the Street in Late Medieval and Renaissance Italy" in Urban Landscapes: International Perspectives, ed. J. Whitehand and P. Larkham, London, 1992, 69-113. 
26 Nicholas Ryckemans, after an anonymous Genoese design, palace of Agostino Pallavicino, Strada Nuova, engraving, from Peter Paul Rubens, Palazzi di Genova, Antwerp, 1622 (from Labò I Palazzi di Genova di Pietro Paolo Rubens, 122).

27 Antonio Lafreri, Palazzo Caprini, Rome, ca. 1510, by Donato Bramante, 1549, engraving (from Heydenreich and Lotz, pl. 166)

lar workshops were relegated to the alleys between the palaces (Figs. 17, 21, 22, 28), which resemble medieval vicoli more than Renaissance strade, foregrounding the ceremonial function of the palace facades for representation of the old noble

96. In the Royal Institute of British Architects album and Rubens's Palazzi di Genova (as in n. 5), detailed room designations are given for the Strada Nuova palaces (Labò, as in n. 5, 103 and passim). On the ground floor, these include "stanza per servitori," "tintori," "cantina," "scuola," and so on. The published plans suggest autonomous, internal functions for these service rooms within each palace, but it seems that these urban residences had ground-floor shops on their sides for commercial activity and rental income during the 16 th and 17 th centuries. Ground-floor negozi (shops) are prevalent in documents and remains of medieval and Renaissance palaces, commissioned by commercial elites in Genoa. In a larger study, the side alleys and piazza spaces in back of the Strada Nuova palaces need consideration as an entire borgo environment. These alleys resemble, and they seem to continue, the narrow, dark medieval market streets of the old city below. Were they part of porous Renaissance palace plans, or later openings of these palazzi to the public during the 19 th and 20 th centuries?

97. On the symbolism of the orders, see John Onians, Bearers of Meaning: The Classical Orders in Antiquity, the Middle Ages, and the Renaissance, Princeton, N.J., patrons, a "leisure" class within their "Roman" city. 96 The dominant Doric order and lions' heads on the rustic-pilasteraedicular facade (Figs. 1, 21, 22, 26) and the elegant freestanding Doric column screen and courtyard inside the palace symbolized the "Doric" race, the "antique" virtue, fortitude, strength, and "ancient" origins of the old noble family: their antica nobiltä. ${ }^{97}$ Alessi's classical style became synonymous, as Rubens said, with the Genoese nobility.

Diagonally across the street, Tobia Pallavicino, Agostino's brother, financed a truly extraordinary building campaign and family display with a contemporary palace and a suburban villa, located within walking distance outside the nearby city gate of Portello to the northeast in the region of the Murtedo (or Mortedo) on a hillside with commanding views over Genoa and the Strada Nuova. Both the Strada Nuova palace and the Murtedo villa suburbana featured a similar rustic-pilaster facade style, identified with the family group (Figs. 7, 10, 11, 21: nos. 4, 29, 30). ${ }^{98}$ Commission and construction documents on the purchase of properties, marble, and pietra di Promontorio reveal the close collaboration between Agostino and Tobia Pallavicino in the execution and presentation of their Strada Nuova palaces, as well as Tobia's villa, called "delle Peschiere" because of the monumental fish ponds on the garden terraces. ${ }^{99}$ Contemporaries called Tobia "il Re dell'allume" (the King of alum) because he carried on the tradition and example of the Sienese banker Agostino Chigi in his monopoly over papal alum mining at Tolfa, required for dyeing cloth; his phenomenal wealth fed this frenzy of urban and suburban building. ${ }^{100}$ In a dialogue comparing the artistic splendors of Genoa and Venice, Bartolomeo Paschetti, a Genoese humanist, boasted that Tobia spent " 120,000 scudi" on his palace and villa in a city "full of such commodious houses and of such superb palaces, that seem more appropriate to Princes, or Kings, than the habitations of private persons." 101

Judging from an anonymous Genoese drawing made for Rubens's Palazzi di Genova (Fig. 29), the palace of Tobia Pallavicino highlights a rustic Doric order similar to that of the palace of Agostino Pallavicino (Fig. 26). Here, however, it is confined to the ground floor in the form of a central, projecting, Doric pedimental entrance portal-image and physical presence of the antiquity and strength of family. ${ }^{102}$ The "sacred" Greek temple front entry was flanked by segmental and pedimental window and mezzanine frames in rhythmic, symmetrical order. ${ }^{103}$ This remarkable facade draw-

1988; Burroughs (as in n. 95), 7-30; and idem, "Michelangelo at the Campidoglio: Artistic Identity, Patronage, and Manufacture," Artibus et Historiae, xIv, no. 28, 1993, 85-112.

98. For the palace of Tobia Pallavicino, see Poleggi, chap. 7: for the Villa Pallavicino "delle Peschiere," see De Negri et al, (as in n, 54), 100-117; Magnani (as in n. 54), 68-74; and Salzer (as in n. 5), 190-250.

99. Poleggi, 101, 130, 451ff.

100. Already involved in the Grimaldi papal alum trade of 1541-53. Tobia and his older brother Agostino assumed the monopoly in 1566-78 (Poleggi, 129). For this key economic position and the artistic patronage model of Agostino Chigi at the Villa Farnesina in Rome, see Melissa Meriam Bullard, Filippo Strossi and the Medici, Cambridge, 1980; Coffin (as in n. 50), 87-110; and Ingrid Rowland, "Render unto Caesar the Things Which Are Caesar's: Humanism and the Arts in the Patronage of Agostino Chigi," Renaissance Quarterly, XXXIX, 1986, 673-730.

101. "... ripiena di tante commode case e di tanti superbi palagi, che 
ing activates a lively play of light and dark, straightedge lines and stippled shadows, executed in pen and brown ink and brown wash across the rustic elements, a pictorial architecture addressing the street. Across the bottom of the drawing, an inscription underscores this pictorial intent, specifying local materials and blended coloristic visual effects: "Le bugne rustiche sono di pietra di fina. Le finestre et la porta e di marmaro[.] Li pilastri ionichi sono di pietra di finale[,] il cornicione di calcina tinto di color di fina[,] il parapetto di color di finale" (The rustic bosses are of pietra di Finale. The windows and the portal are of marble. The Ionic pilasters are of pietra di Finale, the entablature of mortar tinted to the color of pietra di Finale [light brown or tan], the parapet of the same color of Finale). What was not made in reality could be made in illusion. ${ }^{104}$

Across the piano nobile of Tobia's palace, a refined Ionic pilaster order in light and more porous pietra di Finale (from Liguria's western Riviera) is supported in Vitruvian manner over the Doric base of pietra di Promontorio, polarizing the bichromatic colorism of the palace of Agostino Pallavicino. Tobia's piano nobile densely articulates the alternating aedicular windows within a vertical bay system, united in tripartite division by a central Bramantean balustrade-balcony, a viewing platform for the family over the urban "theater" space (Figs. 19, 20, 29). The linear complexity of this Mannerist facade architecture not only imitates but also enriches Roman examples, such as Bramante's Palazzo Caprini (Fig. 27), Giulio Romano's Palazzo Maccarani, and the late Raphael school Palazzi Alberini-Cicciaporci, Caffarelli-Vidoni, and Jacopo da Brescia (Costa). ${ }^{105}$ Tobia's Villa Pallavicino "delle Peschiere" (Fig. 30) extended this Vitruvian progression of rustic and refined Doric to Ionic and Corinthian pilaster orders into the landscape, through a series of monumental garden terraces on axis with the open, tripartite block of the belvedere. This classical ascent from city to villa further heightened the Pallavicino facade style, which Paschetti compared to "a city above the city." 106 "

The second palace style was "the stucco block," whose flatter, more austere exterior, painted with architectural and figural decorations, contrasted with the rich sculptural decorations of the Pallavicino palaces. This second type was patronized by the Spinola family all along the Strada Nuova (Fig. 21: nos. 2, 5, 6, 8-10), again setting up a symbolic rapport among family clan members along the linear piazza. ${ }^{107}$ Across from Agostino Pallavicino's palace, the palace

paiano piu tosto di Principi, che di Rè esser palagi, che habitationi di private persone"; Bartolomeo Paschetti, Le bellezze di Genova: Dialogo del S. Bartolomen Paschetti, Nel quale si ragiona del sito della cittì, degli huomini Mlustra antichi moderni, e delle Donne similmente, con altre cose notabili, Genoa, 1583, 5v. In the dialogue, Paschetti attributes this statement to Giulio Pallavicino, nephew of Tobia and son of Agostino, suggesting further the close ties (as well as competition) among these branches of the family consorteria; for the complete passage, see Paschetti, 5-7. Cf. Doria, 16.

102. This continued focus on the family palace portal as an image of nobility and privilege in Genoa, decorated with a stemma, classical orders, reliefs, fertile foliage, and portraits, comes from the famous Genoese palace portals of the 15 th and early 16 th centuries; see Hanno-Walter Kruft, Portali Genoxesi del Rinascimento, Florence, 1971. For the drawing in the Royal Institute of British Architects album (Fig. 29), see Lever et al. (as in n. 5), no. 6, 159, and n. 5 above.

103. Poleggi, 134-35.

104. The Italian cursive style of this inscription is different from Rubens's
28 Salita between the Strada Nuova palaces with insular shops and Palazzo Grimaldi in background (photo: George L. Gorse)

of Pantaleo Spinola (Figs. 21: nos. 2, 31) presents a solid, firm tripartite cube with central triptych window balustrade above a heavy, allegorical, Doric segmental entrance portal with coat of arms displayed between flanking towers. This palace type was inspired by the ancient Roman imperial portico villa with advanced side towers, introduced to Genoa by Alessi's villa of Luca Giustiniani in Albaro (Fig. 13), with its similar tripartite form (but with exterior orders and a belvedere loggia, appropriate to the countryside) and symmetrical arrangement of interior rooms along a central longitudinal hall,

handwriting in his extensive Italian correspondence (cf. Max Rooses and Charles Ruelens, Correspondence de Rubens, 6 vols., Antwerp, 1887-1909), and the use of Genoese terminology throughout (e.g.. fina for finale) indicates a Genoese rather than northern European author. See Labò (as in n. 5), 21-22. who makes the case for the authorship of these drawings by a Genoese artist rather than by Rubens or another Flemish artist. This is substantiated by Rubers's preface to his Palazzi di Genovk, where he speaks of "acquiring" these drawings "at great effort and expense" for publication. This acquisition (rather than personal execution) of the drawings indicates Rubens's intent to remain true to the Alessian-pictorial style of the Genoese palaces and villas, so different from contemporary northern European architecture of the late 16 th and early 17 th centuries (which Rubens wanted to reform through this unique humanist architectural model book). See n. 5 above.

105. Poleggi, 134-35; Frommel (as in n. 76), 111, pls. 1, 21, 25, 32, 139.

106. Paschetti (as in n. 101), 7.

107. Poleggi, chaps. 8, 9, 11, 15 . 
29 Anonymous Genoese drawing, acquired by Peter Paul Rubens for his Palazzi di Genova, Antwerp, 1622, palazzo A: palace of Tobia Pallavicino. Collection of British Architectural Library, Royal Institute of British Architects, London

similar in type to the patrician palaces of Jacopo Sansovino in Venice and Michele Sanmicheli in Verona and Venice. ${ }^{108}$

This Genoese dialogue with the patrician palaces of other Italian cities continued in the third type, exemplified by the palace of Nicolosia Lomellino (Fig. 21: nos. 7, 32): the elegant "grotesque style." 109 The lot size of the Lomellino palace (Fig. 22: no. 7) was reduced owing to the expansiveness of the neighboring palace of Nicolo Grimaldi, "il Monarca," to the west. However, the vertical proportions of this centrally located palace draws attention to its uniquely delicate linear patterns of antique stucco decoration, accentuated in the light pen and brown ink and brown wash patterns of another preparatory drawing for Rubens's Palazzi di Genova (Fig. 32) ${ }^{110}$ The sources of this refined Maniera palace style with grotesque trophies in stucco hanging from the facade are in the Roman architecture of late Raphael, in particular the Palazzo Branconio dell'Aquila. ${ }^{111}$ The iconography of this palace style was triumphal through figuration, with its festive display of trophy reliefs, garlands, medallions, cartouches, grotesque heads, looped strapwork, and victory herms, just as the other palaces were triumphal through their architectural representations.

The fourth palace style, presented by the palace of Franco Lercari (Figs. 21, 22: nos. 3, 33), was "the villa style." This palace was extraordinarily open for its urban location, like a classical villa suburbana, and well related to its hillside site, connecting the city and country. ${ }^{112}$ Paired towers from the Roman portico tradition flanked a loggia screen on the urban space, leading into a large courtyard in Vitruvian Doric and Ionic order, and an atrium, staircase, and rear garden court. The open screen architecture and flanking towers of the Palazzo Lercari recall Venetian medieval palaces on the Grand Canal, as well as central Italian communal palaces (for example, the Palazzo dei Conservatori in Rome), and the U-shaped block form of the Lercari palace (Figs. 12, 22, 33) was directly modeled on Alessi's Villa Grimaldi in Carignano, near S. Maria Assunta. ${ }^{113}$

This stylistic integration of palace and villa architecture was particularly apparent in the most grandiose of all the Strada Nuova palaces, the palace of Nicolò Grimaldi on the west end (Figs. 12, 21, 22: nos. 9, 24, 25), next to his family-Agostino, Gerolamo, Giambattista, and Luca Grimaldi-whose palaces and gardens faced the Salita di S. Francesco di Castelletto. ${ }^{114}$ This palace indeed was worthy of a "monarch." It reached Roman proportions, similar to the contemporary imperial aspirations of the Medici Palazzo Pitti in Florence, fulfilling the public representational needs of the leading banker to King Philip II of Spain, who exerted tremendous power within the old noble corporate republic. Nicolò Grimaldi bought three Strada Nuova lots, and thus his palace dominated the western half of the street near the grotto. A salita came up from the city on axis with the entrance portal to the Grimaldi palace (Figs, 12, 17, 22, 28). This di sotto in su approach continued up through the palace, from the entrance facade and portal into the entrance vestibule, to the raised courtyard and rear garden, ascending through the diverse levels of urbs et rus via a monumental royal staircase (Figs. 24, 25). The steep ascent from dark, narrow medieval vicolo (Fig. 28) to light-filled, wide Renaissance strada (by Genoa's stringent standards, Fig. 1) linked the "old" and "new" city, while highlighting their distinctions of style, representation, and urban environment. They became two interconnected worlds.

Above, in back, the Palazzo Grimaldi reunited with a
108. Cf. Sansovino's Ca' Corner and Samicheli's Palazzi Grimani and Canossa, in Heydenreich and Lotz (as in n. 53), figs. 67-71 and pl. 242.

109. See Poleggi, chap. 12, 277-300. The origins of the Roman "grotesque" style are illuminated by Nicole Dacos. Lat derouzerte de la Domus Aurea of to formation des grolesques à la Renaissance, London, 1969.

110. Lever et al, (as in n. 5), no. 27, 166.
111. Poleggi, 282; Frommel (as in n. 76), III, pls. 7-9 (also the Palazzo Capodiferro-Spada with heroic "ancestor" portraits, ibid., pl. 28).

112. Poleggi, chap. $14,349-72$.

113. Originally built for Giovanni Battista Grimaldi, this atrium forecourt villa (resembling Early Christian churches such as old St. Peter's) was later purchased by the Cibo and then Sauli families; sec De Negriet al. (as in n. 54), 
30 Villa Pallavicino "delle Peschiere," 1555-65, garden facade (from Isabella Ferrando and Tiziano Mannoni, Liguria: Ritratto di una regione, Genoa, 1988 , fig. 72 )

medieval family chapel in S. Francesco di Castelletto (Figs. 12, 17, 24), creating a traditional palace-church complex, similar to European royal palace-palatine chapel groups but reminiscent of the medieval Genoese albergo with its local chiesa di gentilizia (Figs. 7, 14, 15). The medieval and Renaissance city formed one complex layered system. The extensive excavations for the Grimaldi palace, including the building of terraces (similar to a formal garden) into the hillside (12 meters high) from the street to the church, began in 156567. ${ }^{115}$ Columns and walls were carved and put in place after 1568-70. ${ }^{116}$ The magnificent Doric pilaster facade, with its high, rusticated base in light-colored and richly textured pietra di Finale, gave the palace an "antique" Roman appearance, resembling travertine, but filled with fossilized seashells, appropriate to the "ancient" Genoese maritime republic, its source of wealth. The palace extends along the Strada Nuova, making it similar in lateral expansion (but different in style) to the ducal Palazzo Pitti in Florence along its grand ceremonial entrance piazza. ${ }^{117}$

But the entrance piazza of the Grimaldi palace was actually inside the building (Figs. 21, 22: nos. 9, 24, 25). Grimaldi's entrance vestibule ascended by a single staircase through a Doric column screen into the light of a tall courtyard surrounded by Doric and Ionic orders on two floors, the colonnades acting as an open screened enclosure, giving dramatic access to the different levels. At the back of the courtyard, a T-shaped triple-ramped staircase ascended upward and forward through the two residential stories to what had once been the garden entrance into $\mathrm{S}$. Francesco. Grimaldi's royal staircase borrowed heavily from the contemporary Spanish Escorial's open royal hall staircase, which reveals the Genoese banker's close financial and cultural ties to the court in Madrid. ${ }^{118}$ This was royal scenographic architecture at its highest level. Yet, in design and visual effect, this monumental cortilepiaza was also an interior architectural version of the ceremonial entrance plaza and gardentheater terraces of the papal Belvedere Courtyard in Rome

31 Nicholas Ryckemans, after an anonymous Genoese design, palace of Pantaleo Spinola, Strada Nuova, engraving, from Peter Paul Rubens, Palazzi di Genova, Antwerp, 1622 (from Labò, I Palazzi di Genova di Pietro Paolo Rubens, 140) passim, which richly deserves publication.

118. See George Kubler, "Galeazzo Alessi e I'Escuriale," in Lotz et al. (as in n. 5), 599-604; and Wilkinson (as in n. 89), 65-90. 
32 Anonymous Genoese drawing, acquired by Peter Paul Rubens for his Palazzi di Genova, Antwerp, 1622, Palazzo Lomellino, Strada Nuova. Collection of British Architectural Library, Royal Institute of British Architects, London

(Fig. 34). ${ }^{119}$ The celebration of power and court life took place within this ascending perspective space.

After Nicolò's death, Prince Giovanni Andrea Doria quickly bought the Grimaldi palace in 1596, acquiring its imposing imperial presence over the city to complement his renovated monumental villa and galley fleet station at the harbor entrance (Figs. 11, 12). ${ }^{120}$ Prince Doria occupied both these urban and suburban palaces, as well as his old medieval ancestral albergo near S. Matteo (Figs. 7, 14, 15). For all of the Strada Nuova families, the "new street" did not replace but coexisted with their continued control of an old albergo piazza. As conservator of the republic and successor to Andrea Doria, Prince Giovanni Andrea made the Grimaldi palace the center of his "court." He added Doric end loggias to the palace facade and systematized the flanking giardini pensili over the

119. James Ackerman, "The Belvedere as a Classical Villa," foumal of the Wartrug and Courtauld Institutes, XIV, 1951, 70-91; idem, The Cortile del Betwedere. Vatican City, 1954; Coffin (as in n. 50), 69-87, with examples of its major influence on Renaissance court centers.

120. Poleggi, 304-9.

121. This parallels Giovanni Andrea Doria's addition of end loggias on his suburban harbor villa in Fassolo and his country coastal villas in Loano and Pegli; see Magnani (as in n. 54), 27-55, 115-24; and Salzer (as in n. 5), 251-99. Giovanni Andrea Doria made this longitudinal villa type with end loggias a seignorial symbol of his old noble leadership.

122. See Caterina Marcenaro, "Una fonte barocca per l'architetura or-
33 Palazzo Lercari, Strada Nuova, reconstruction drawing without 19th-century glazing (from Reinhardt, pl. 58)

Strada Nuova (Figs. 22, 24), further accentuating the seignorial villa elements of this now nearly royal palace. ${ }^{121}$

With the weakening influence of the sixteenth-century elite, new nobles arrived on the Strada Nuova during the seventeenth and eighteenth centuries. The brothers Gian Francesco and Ridolfo Brignole Sale commissioned in 1671 the dramatic Palazzo Rosso (Figs. 21, 22: no. 18), which presents a bright red stone, tripartite rusticated facade, higher in cornice line than the previous Renaissance palaces, and an expansive interior reception vestibule, courtyard, and rear garden belvedere over the port. ${ }^{122}$ This palace became the locus of a comprehensive decorative program, competing with other Strada Nuova palaces in the glorification of family within the aristocratic republic, with an extensive collection of paintings, tapestries, sculptures, and other precious ob-

ganica: II palazzo Rosso di Genova," Paragone, no. 139, July 1961, 24-49 Poleggi, chap. 16, 393-401.

123. See Doria; Piero Boccardo, "Fonti d'archivio per una storia degli arazzi a Genova," Siudi di storin delle arti (Genoa), no. 5, 1983-85, 113-30; Arthur K Wheclock, Jr., et al., Anthony Van Dyck, exh. cat., National Gallery of Art, Washington, D.C. 1990 . The architecural symbolism of the Strada Nuova and the Alessian style for the Genoese nobility were integral to Anthony Van Dyck's monumental portraits of these family members, where the theatrical setting and columnar architecture are synonymous with noble portrait pose, costume and status. In scale, style, and iconography, these portraits were made for 
jects, an expression of noble rank through conspicuous consumption and display. ${ }^{123}$ The duchess of Galliera, Maria Durazzo Brignole Sale, later built the Palazzo Bianco on the site of Luca Grimaldi's palace in 1714 (Figs. 21, 22: no. 11), turning its facade orientation 90 degrees from the Salita di S. Francesco di Castelletto to the Strada Nuova. ${ }^{124}$ One would surmise from this dramatic (and expensive) change that the duchess preferred to face her relatives across the wide street in the Palazzo Rosso rather than the Grimaldi family clan on the narrow salita.

To the west of the Strada Nuova, the new noble Balbi family commissioned the Strada Nuovissima (or Via Balbi), built between 1602 and 1620, another major axial street. Modeled after the Via Aurea, it competed with the old noble center but was open at both ends as an interior strada di transito for aristocratic carriage and pedestrian traffic between the western city gate of S. Tomaso and the Piazza della Nunziata (Figs. $10,35) .{ }^{125}$ This open perspective palace street gave visibility to the nobili nuovi, just as the closed, linear piazza of the Strada Nuova had for the vecchi. The Lombard architetto camerale of the patres communis, Bartolomeo Bianco, designed the Strada Nuovissima in collaboration with the Balbi family. ${ }^{126}$ It combined monumental Baroque palaces, which deliberately echoed (and competed with) the Strada Nuova-particularly the Grimaldi-Doria palace (Fig. 24) —with sweeping horizontal fronts, scenographic interior courtyards, and end loggias over the street. In particular, the monumental, scenographic, street-facade-portal-vestibule-courtyard-staircase-gardenchapel sequence of the Collegio dei Gesuiti (now Università di Genova) directly competed with the theatrical staircase progression of the Grimaldi palace (Figs. 25, 36), prefiguring Stefano della Bella and Giambattista Piranesi in these ascending stages for the ceremonial functions of the late Renaissance and the Baroque. This Baroque fusion of Balbi palaces with monumental churches, monasteries, and collegi of the Jesuit and Discalced Carmelite orders along the open axial street formed a palace-church ensemble that celebrated the family-supported Catholic reform movements of the early seventeenth century. ${ }^{127}$ The patronage of new nobles, open street perspective, expansive palace design, exuberant interior decorations, integrated collection display, and this mixture of palaces and churches distinguished the Baroque Via Balbi from the Renaissance Strada Nuova.

At the same time as the triumphal entry of new nobles onto the Strada Nuova with the building of the Brignole Sale Palazzo Rosso in $1671-77$, the patres communis proposed a public project to tear down the garden wall and grotto at the west end of the street to connect the Via Aurea with the Piazza della Nunziata and Via Balbi. ${ }^{128}$ This plan eventually led to

125. For the context of this commission, see Poleggi and Cevini (as in n. 13), chap. 7, 121-60. On the Via Balbi, see Luciano Grossi Bianchi and Ennio Poleggi, "La strada del Guastato: Capitale e urbanistica genovese agli inizi de Seicento," in Dalla cätra preindustriale alla città del capitalismo, ed. A. Garacciolo, Bologna, 1975, 81-93.

126. Rubens, passim, makes this connection between the Strada Nuova and the Via Balbi palaces, the Alessian Renaissance to the Bianco Baroque.

127. For the palaces and churches on the Via Balbi, see Luciana Profumo Müller, Bartolomeo Bianco architetto e il barocco genozese, Genoa, 1968; Giovanna
}

34 Artist unknown, General view of Belvedere Courtyard, ca, 1590. Collection Centre Canadien d'Architecture/Canadian Centre for Architecture, Montréal

the clearing of another Strada Nuovissima (now Via Cairoli) in 1786 (Fig. 10), which connected these two urban centers as part of a Baroque circulation system, somewhat similar to the construction of connecting avenues through Rome and other European Baroque cities (Fig. 16). Thus, a beltway of strade nuove ran all the way from $\mathrm{S}$. Tomaso in the west to Carignano in the east. This Baroque control of space, and the dramatic classical imagery invented as a visual language for the aristocratic republic, were appropriated in turn by the bourgeois (or post-Napoleonic) city of the nineteenth century with the demolition of the city walls, the extension of grand Beaux-Arts boulevards into the suburbs by the Genoese architect Carlo Barabino, and the creation of a train and then automobile corridor through the sprawling, populous modern industrial city. ${ }^{129}$

But to return to the Renaissance and Baroque periods, John Evelyn's famous travel description of Genoa in 1644 placed Peter Paul Rubens's illustrations of the Strada Nuova palaces at the center of an urban scenography:

The city is built in the hollow or bosom of a mountain, whose ascent is very steep, high, and rocky, so that, from the Lantern and Mole to the hill, it represents the shape of a theater; the streets and buildings so ranged one above another, as our seats are in play-houses; but from their materials, beauty, and structure, never was an artificial scene more beautiful to the eye, nor is any place, for the size of it, so full of well-designed and stately palaces, as may be easily concluded by that rare book in a large folio which the great virtuoso and painter, Paul Rubens, has published, though it contains [the description of] only one street [the Strada Nuova]. ${ }^{130}$

Terminiello Rotondi, "Bianco, Bartolomeo," in Dizionario biografico deghi italiani, x, Rome, 1968, 225-26; Armando di Raimondo and Luciana Profumo Müller, Bartolomeo Bianco e Genova: La controversa patemità dell opera architettonica tra' 500 e' 600 , Genoa, 1982.

128. Poleggi, 485-86, doc. 31, Nov, 24, 1666

129. For the 19th and 20th centuries, see Poleggi and Cevini (as in n. 13), chaps. 8-10; Emmina De Negri, Ottocento e rinnovamento urbano, Carlo Barabino, Genoa, 1977.

130. Diary and Correspondenre of John Evelyn, ed. William Bray, L, London, $1857,84-85$, Genoa, Oct. $17,1644$. 
35 Giolf, Perspective view of Via Balbi from the east, 1769. Genoa, Collezione Topografica del Comune space-a new urban form, the linear piazza-came into being, and for which it functioned.

\section{Appendix}

Strada Nuova Fact Sheet by Via Garibaldi Number (Figs. 21, 22)

Piazza del Fonte Moroso on east end, Spinola di Luccoli and Pallavicino family quarters.

1. Palace of Agostino Pallavicino, alum trade, Tolfa. Atributed to Galeazzo Alessi, 1558-65; Bernardino Cantone, executant architect. Bought by Cambiaso family end of 18th century; Banco di Napoli, 1921. Rusticated gray pietra di Promontorio and smooth white Carrara marble facade; dense Mannerist aedicular facade, cf. Alessi, Palazzo Marino, Milan; interior atrium, staircase, courtyard. Andrea and Ottavio Semino decorations, 1565-70: Alexander the Great, Council of Gods, Villa Views and Aristocratic Country Life, Apollo and Muses, Rape of Sabines. Rubens, Palazzi di Genova, "Palazzo del Sig. A. Pallavicino"; Poleggi, chap. 6.

2. Palace of Pantaleo Spinola, banker. Architect Bernardo Spazio, 1558-64. Taddeo Carlone, segmental entrance portal with Vigilance and Prudence. Now Banco di Chiavari e della Riviera Ligure. Unifying band of balcony balustrades; plane facade surface with advanced side elements; interior atrium, staircase, vestibule; mid-17th-century octagonal courtyard and nymphaeum in back. Giovanni Carlone and Domenico Piola paintings, 1630s-50s: Putti and Virtues, Allegory of Peace. Rubens, "Palazzo del Sig. A. Spinola"; Poleggi, chap. 8.

3. Palace of Franco Lercari, banker, called "il Ricco" (the Rich). Architect unknown, 1571-78; plan based on Alessi, Villa Grimaldi in Carignano. Still private palace. Open loggia screen facade with side towers; rustic blocks and diamond pilasters, ground floor; interior courtyard in front, vestibule, staircase, rear garden courtyard. Decorations: Ottavio Semino, Fall of Giants (1578) after Perino del Vaga's Fall of Giants in Villa Doria, Fassolo; Luca Cambiaso, Lercari Building Scene; Andrea Semino, Story of David; Lazzaro Calvi, Cycles of Joseph and Abraham. Rubens, "Palazzo K"; Poleggi, chap. 14.

4. Palace of Tobia Pallavicino, "il Re dell'allume" (the King of alum); offices in Rome, London, Antwerp; ambassador to court of France; also patron of Alessian Villa Pallavicino "delle Peschiere" in Murtedo. Architects B. Cantone and Giovanni Battista Castello, called "il Bergamasco," 1558-78. Bought by Giacomo Filippo Carrega, 1710; to Cataldi family, 1830; Camera di Commercio, 1922. Rusticated ground floor with alternating pedimental and segmental windows; Ionic pilaster facade, piano nobile; central three-bay balcony; reversed window sequence; background of rusticated pietra di Promontorio, Carrara marble elements. Interior atrium, staircase, vestibule, to rear U-shaped courtyard and gallery loggia. G. B. Castello, atrium "grotesque" decorations. Third floor added, 1727-46; 18th-century renovation of gallery, rococo decorations, and courtyard in back; gallery decorations: Lorenzo de Ferrari, Mt. Olympus and Story of Aeneas, 1743-44. Rubens, "Palazzo A"; Poleggi, chap. 7.

5. Palae of Angelo Gintonni Spinola, military commander and banker. Architect B. Cantone, 1558-64. Now Banca d'America e d'Italia. Originally painted facade (now faded) with Doric and Ionic pilasters on ground floor and piano nobile, alternating pedimental and segmental window frames; ground-floor windows with rusticated keystones, for reconstruction see Rubens, "Palazzo F"; original U-shaped plan, elongated 20th century; atrium, staircase, U-shaped courtyard. Decorations: Lazzaro Tavarone, Seated Spinola Ancestors with Trophies in entrance vestibule rose above the medieval communal center, veiling underlying social tensions out of which this spectacular urban 
after Perino del Vaga's Doria Ancestors in Loggia degl'Eroi of Villa Doria, Fassolo; G. B. Castello, A. Semino, L. Tavarone, Spinola Battle Scenes; cycles of Julius Caesar, Alexander the Great, Roman Battle Scenes, Classical Villas, Seasons, and grotteschi on vaults. Poleggi, chap. 9.

6. Palace of Giambattista Spinola, banker-merchant. Architects G. B. Castello and Bernardino Cantone, 1563-67. Doria purchase, 1723; now Banca d'America e d'Italia. Originally three-story pilaster facade: Vitruvian Doric, Ionic, Corinthian; added story end of 17 th century; new facade by Giovanni Antonio Ricca il Vecchio; atrium, courtyard, giardino pensile. Decorations: A. Semino, Perseus and Andromeda, Embassy of Oberto Spinola to Barbarossa, Jove and Danae, Fall of Phaeton. Rubens, "Palazzo I"; Poleggi, chap. 11.

7. Palace of Nicolosia Lomellino, banker. Architects G. B. Castello and B. Cantone, 1563-66. Bought by Centurione, 1614; then Pallavicino, Raggi, Andrea Podestà, mayor 1866-95. Bergamasco Mannerist trophy facade; oval atrium, staircase, U-shaped courtyard to nymphaeum. Centurione expansion in back; Domenico Parodi nymphaeum, early 18th century. Mythological frescoes by Marcantonio Franceschini, D. Parodi, Lorenzo de Ferrari, and Giacomo Antonio Boni. Rubens, "Palazzo IX del Sig. L. Centurione"; Poleggi, chap. 12.

8-10. Palace of Giacomo and Lazzaro Spinola. Two palaceshouseholds. Medieval building type with common wall, built 1584-88; double portal, leading to two reduced atriums, staircases, rear courtyards. Decorations: Gregorio de Ferrari, Hercules Cycle; L. Tavarone paintings of Adorno Exploits, 1624. Rubens, "Palazzo X of Giacomo Saluzzo and Giovanni Battista Adorno"; Poleggi, chap. 15.

9. Palace of Nicolò Grimaldi, called "il Monarca" (the Monarch); major banker of Philip II. Architects Domenico and Giovanni Ponzello, 1565-79; T. Carlone sculpture. Bought and enlarged by Giovanni Andrea Doria, 1596; son Carlo, duke of Tursi; Palace of Savoy, 1820; Palazzo del Municipio after 1848. Occupies 3 lots, with a face 88 meters long; pilaster facade, portal, to atrium, stairs, courtyard, grand staircase on ascending levels. End loggias and giardini pensili added 1597. Rubens, "Palazzo del Don Carlo Doria"; Poleggi, chap. 13.

12. Palace of Baldassarre Lomellino. Architect G, Ponzello, 1562 66. Completely transformed after 1770 by Andrea Tagliafichi and Charles de Wailly for Cristoforo Spinola; heavily damaged, 1942. Atrium, staircase, loggia on axis with giardino pensile in back.
Paintings and stucco decorations: A. Semino and G. B. Castello, Story of Aeneas. Rubens, "Palazzo XI del Sig. H. Salvago"; Poleggi, chap. 10.

14-16. Palazzo delle Torrette. Architect Giacomo Viano, 1716. Built by Doria-Tursi family as setback palace front to Palazzo DoriaTursi (no. 9). Central arch on access to Doria-Tursi portal and interior courtyard. View down Vico del Duca to Via della Maddalena (Fig. 28). Forecourt shops and storerooms inside for Doria-Tursi palace across the street (no. 9).

11. Palace of Maria Durazzo Brignole Sale, duchess of Galliera. Architect Giacomo Viano, 1714. Built on site of Luca Grimaldi Palace, which faced west on Salita di S. Francesco, 1540s. Palazzo Doria-Tursi (no. 9) pilaster facade type; atrium and raised courtyard. Palazzo Bianco municipal art museum, 1888; heavily damaged, 1942. Poleggi, chap. 5.

18-20. Palace of Gian Francesco and Ridolfo Brignole Sale, 1671-77. Architect Pier Antonio Corradi. Palazzo Rosso municipal art museum, 1874. Festive red painted facade ends Baroque section of Strada Nuova; atrium, loggia, courtyard sequence. Poleggi, chap. 16.

Piazza Meridiana and Strada Nuovissima (Via Cairoli) opened at west end, 1786. Luca Grimaldi garden wall torn down and Strada Nuova connected to Piazza della Nunziata and Via Balbi.

\section{Frequently Cited Sources}

Doria, Giorgio, "Investimenti della nobiltà genovese nell'edilizia di prestigio (1530-1630)," Studi storici, xxvH, 1986, 5-55.

Labò, Mario, "Strada Nuova (più che una strada, un quartiere)," in Scrilli di storia dell 'arte in omore di Lionello Venturi, I, Rome, 1956, 403-10.

Poleggi, Ennio, Strada Nuota, una lotizzazione del Cinquecento a Genova (1968), 2d ed., Genoa, 1972.

Rubens, Peter Paul, Palazzi di Genova (Antwerp, 1622), facsimile ed., Palazzi Antichi di Genova and Palazzi Moderni di Genowa, intro. Alan Tait, New York. 1968 .

George L. Gorse is Viola Horton Professor of the History of Art at Pomona and Scripps Colleges. He has published articles on the artistic patronage and iconography of the Genoese admiral Andrea Doria, on the villa of Andrea Doria in Genoa, and Genoese architecture, urbanism, and ceremony [Deparlment of Art and Art History, Pomona College, Claremont, Calif. 91711, ggorse@pomona.edul. 